\title{
Ecology and distribution of living ostracod assemblages in a shallow endorheic lake: The example of Lake Trasimeno (Umbria, central Italy)
}

\author{
Marta MARCHEGIANO,${ }^{1 *}$ Elsa GLIOZZI, ${ }^{2}$ Simona CESCHIN,${ }^{2}$ Ilaria MAZZINI, ${ }^{3}$ Thierry ADATTE, ${ }^{4}$ Roberto MAZZA, ${ }^{2}$ \\ Stefano GLIOZZI, ${ }^{5}$ Daniel ARIZTEGUI ${ }^{1}$
}

${ }^{1}$ Department of Earth Sciences, University of Geneva, Rue des Maraîchers 13, 1205 Geneva, Switzerland; ${ }^{2}$ Department of Science, University Roma Tre, L.go S. Leonardo Murialdo 1, 00146 Rome, Italy; ${ }^{3}$ IGAG CNR, Area della Ricerca di Roma RM1, Via Salaria km 29,300, C.P. 10, 00016 Monterotondo Stazione (RM), Italy; ${ }^{4}$ Institute of Earth Sciences (ISTE), University of Lausanne, Géopolis, 1015 Lausanne, Switzerland; ${ }^{5}$ Business Analytics, IBM Italy, Via Sciangai 53, 00142 Rome, Italy

*Corresponding author: marta.marchegiano@unige.ch

\begin{abstract}
Ostracod assemblages from Lake Trasimeno (Umbria, central Italy), the largest endorheic lake in Italy, were investigated relating their species distribution and ecology to modern physical, chemical and biological parameters. Nineteen living species were collected in the lake (Darwinula stevensoni, Candona (Candona) candida, Candona (Neglecandona) angulata, Fabaeformiscandona fabaeformis, Pseudocandona marchica, Cypria ophtalmica, Ilyocypris gibba, I. salebrosa, I. getica, Cypridopsis vidua, Eucypris virens, Trajancypris clavata, Herpetocypris helenae, Heterocypris salina, H. incongruens, Isocypris beauchampi, Cyprideis torosa, Limnocythere inopinata, and L. stationis). All the identified species belong to the fresh-water Italian ostracod fauna but Cyprideis torosa is documented in an oligohaline athalassic lacustrine environment in Italy for the first time. The occurrence of Ilyocypris salebrosa represents the southernmost record in Italy and the westernmost in Eurasia. The recovery of Limnocythere stationis represents the westernmost record in Eurasia. The distribution of the different ostracods recovered in Lake Trasimeno is linked to the dominant physical and chemical parameters for each ecological niche. Physical and chemical data along with substratum type, grain-size and presence of aquatic macrophytes have been related to different ostracods using a multivariate analyses approach (NMDS, CCA, Spearman's rank correlation test). These results allow to differentiate several ecological niches within the lake and indicate that the main parameters affecting the ostracod assemblages are the aquatic macrophyte coverage, the Total Organic Carbon (TOC) and, to a lesser extent, temperature and type of substrate. Cyprideis torosa and Candona (Neglecandona) angulata have been recovered both in the distal part of the lake and in the lakeshore area. In both cases they are associated with scarce or absent aquatic macrophytes and low amounts of TOC. The alternate dominance of these two species in the distal deeper assemblages seems to be mainly linked with the bottom oxygen availability, being C.(N.) angulata dominant in the most oxygen-depleted sediments and C. torosa dominant in higher oxygen conditions. Along the lakeshore area they are often discovered together with other prevailing species, such as Cypridopsis vidua that is common in very shallow to shallow (20-140 cm) sites with high TOC content, abundant macrophytes and algae, and Limnocythere inopinata, which dominates slightly deeper areas (around 150-210 cm) where the previous species are almost absent. The Spearman's rank correlation test showed significant positive correlation between some ostracods and macrophyte species.
\end{abstract}

Key words: Non-marine ostracods; macrophytes; ecological indicators; multivariate analyses; Mediterranean area.

Received: April 2016. Accepted: February 2017.

\section{INTRODUCTION}

Among benthic invertebrates, ostracods (tiny bivalve crustaceans) are particularly sensitive to environmental changes, being strongly dependent on several physical and chemical factors such as size, depth, energy level, and turbidity of the waterbody as well as temperature, dissolved oxygen content, water chemistry, food supply and substratum nature (including aquatic vegetation) (Rodriguez-Lazaro and Ruiz-Muñoz, 2012).The ability of several cypridoidean species to disperse passively in continental waters, either as adults and/or juveniles through survival in torpid stage and/or as eggs through diapause, leads them to easily populate or re-populate aquatic ecosystems (Mesquita-Joanes et al., 2012). Such characteristics make them a very useful tool for the reconstruction of environmental changes through time, since their calcite shells are easily fossilised and preserved in the sediments. The knowledge of the autoecology and synecology of ostracod species is particularly important when these organisms are used as proxies to investigate the present and past environmental vulnerability (Viehberg and Mesquita-Joanes, 2012).

Endorheic lakes, in particular, are known to be vulnerable ecosystems through time because their hydrological budget is mostly ruled by evaporation due to the absence 
of a surficial drainage output. As a result, endorheic lakes are very sensitive to changes in air temperature and precipitation and thus they deserve special attention in the on-going debate about the possible effects of climate change and human impact on biodiversity and environmental preservation. Lake Trasimeno (Umbria, central Italy) is the largest endorheic basin in Italy. During the last 130 years the basin has been affected by climate changes, especially rainfall and air temperature variations, together with increasing human impact causing relevant lake level oscillations (Ludovisi and Gaino, 2010). These events caused periodical economic crises and the progressive depletion of the aquatic biocoenosis (particularly of the planktonic, macrobenthos, macrophyte and fish communities) (Martinelli, 2012). Such dramatic events are not uncommon in endorheic lakes, as documented, among others, by the historical changes undergone by the large lakes Chad, Aral and Neusiedl, located at different latitudes and under different climate conditions. Lake Chad (semi-arid Sahel region, Africa) was affected by a dramatic desiccation event driven by droughts occurred over the last 50 years, which caused its shrinkage from 25,000 $\mathrm{km}^{2}$ to only $1350 \mathrm{~km}^{2}$ (Helfert and Holz, 1985; Lauwaet et al., 2012). Lake Aral (central Asian desert) underwent repeated lake level oscillations over the past 10-15 kyr, linked to natural climate changes, that culminated into the environmental disaster that is still affecting the lake since 1960 's, due to the irresponsible deviation for irrigation purposes of its two main inflow rivers (Micklin, 2007; Shukla, 2015). The consequences of the Lake Aral shrinking affected dramatically not only the ecological balance of the region and the lake itself (high salinity increase of the waterbody from 10 to $35 \%$; Boomer et al., 1996), but also the health of local population that now uses high saline water for irrigation (causing an important decrease of the agricultural output) and as drinking water (Ataniyazova, 2003). Lake Neusiedl (Austrian-Hungarian border), the largest shallow closed-basin in central Europe, completely dried up between 1866 and 1871 following more than ten temporary desiccation episodes since its formation 13,000 years ago (Soja et al., 2013). The study on Lake Neusiedl ostracods has shown that past changes in the lake level induced the reduction of the Phragmites belt causing a decrease in the ostracod fauna biodiversity (Löffler, 1990) and economic damages to tourism and fishery activities (Soja et al., 2013; Gallinaro et al., 2014).

At present no data are available about Pleistocene changes in water level, despite Lake Trasimeno was supposed to have been settled during the Early Pleistocene (Gasperini et al., 2010). The results of on-going investigations on these older sediments will be useful to disentangle the role of natural and human-induced climatic changes on the evolution of the lake system. The main aim of the present research is to investigate the different living ostracod assemblages and their relation with the main physical, chemical and biological parameters, in order to use these results to reconstruct past environmental and climate variations and their impact on the lake. Additionally, these data improve the knowledge of the living ostracod fauna of Lake Trasimeno, up to now only investigated by von Hartmann (1964), as well as that of the still poorly known ostracod population of the Italian lakes.

\section{METHODS}

\section{Study area}

Lake Trasimeno (Perugia, Umbria - $443^{\circ} 08^{\prime} \mathrm{N}$; $12^{\circ} 06^{\prime} \mathrm{E}$, lake bottom altitude $251.57 \mathrm{~m}$ asl) is the largest lacustrine system of central Italy and the fourth largest Italian lake in size $\left(\sim 120 \mathrm{~km}^{2}\right)$. It is a shallow (average depth $4.7 \mathrm{~m}$, maximum depth $6.3 \mathrm{~m}$ ) endorheic lacustrine basin with few small tributaries. Since 1960, the Rigo Maggiore, Tresa, Moiana and Maranzano ditches were deviated into the artificial Anguillara Channel (Taticchi, 1992). This latter, together with the natural Paganico and Pescia ditches, represents the lake surficial inflows. No natural outflow exists, only an artificial channel built in 1898 near S. Feliciano village spills the Trasimeno waters into the Tiber River through the Caina creek (Fig. 1). There is no consensus concerning the groundwater input to the lake. Whilst Tiberi (1980) excludes any contribution, ARPA Umbria (2005) suggests that $\sim 2.5 \%$ of the total water budget is coming from subsurface waters. Its closed condition makes the hydrological balance of Lake Trasimeno strongly affected by climate variations (precipitation $v s$ evapotranspiration) (Ludovisi and Gaino, 2010; Dragoni et al., 2012). Climate modulates strong lake level variations and at least three negative fluctuations were recorded during the last ninety years (Dragoni et al., 2012). The last low stand occurred between 1988 and 2012 , when the lake level was $1.87 \mathrm{~m}$ below the 'hydrometric zero' (257.33 m asl; refer to http://www.biondiriccardo. it/LAGO/elaborations.htm) (Dragoni et al., 2012).

The shallow character of the lake allows a complete mixing of the water column throughout the year (polymictic lake), producing a continuous homogenization of the physical and chemical parameters such as temperature, conductivity, dissolved oxygen and $\mathrm{pH}$ along the water column. Lake Trasimeno waters are rather well oxygenated (surface DO varies between 5.8 and $12.6 \mathrm{mg} \mathrm{L}^{-1}$; bottom DO 6.6-12.1 $\mathrm{mg} \mathrm{L}^{-1}$ ) with $\mathrm{pH}$ values ranging between 8 and 8.5 and summer maxima around 10 , high $\mathrm{Cl}$ and $\mathrm{Na}$ contents (maximum values of 8.98 and $8.57 \mathrm{~m}^{2} \mathrm{~L}^{-1}$, respectively) and mesotrophic to eutrophic conditions (Taticchi, 1992; Ludovisi and Gaino, 2010; Charavgis et al., 2012). These parameters change seasonally and/or over longer periods: for example, in the last 40 years, conductivity has varied from around 750 in the 70 's to $1700 \mu \mathrm{S} \mathrm{cm}^{-1}$ at the 
beginning of this century (Ludovisi and Gaino, 2010) corresponding to possible variations of TDS of around $1 \mathrm{~g} \mathrm{~L}^{-1}$ of magnitude. Chloride concentration has largely varied too, from 3.63 to $8.98 \mathrm{~m}^{2} \mathrm{~L}^{-1}$ as a result of lake level dropping (Ludovisi and Gaino, 2010).
Along the southern coast of the lake, the bottom sediments are mainly clay and silty-clay whereas sands with variably content of clay and silt dominate along the northern shores (Charavgis et al., 2012). Mineralogical analyses show a great abundance of smectite (Charavgis et al.,

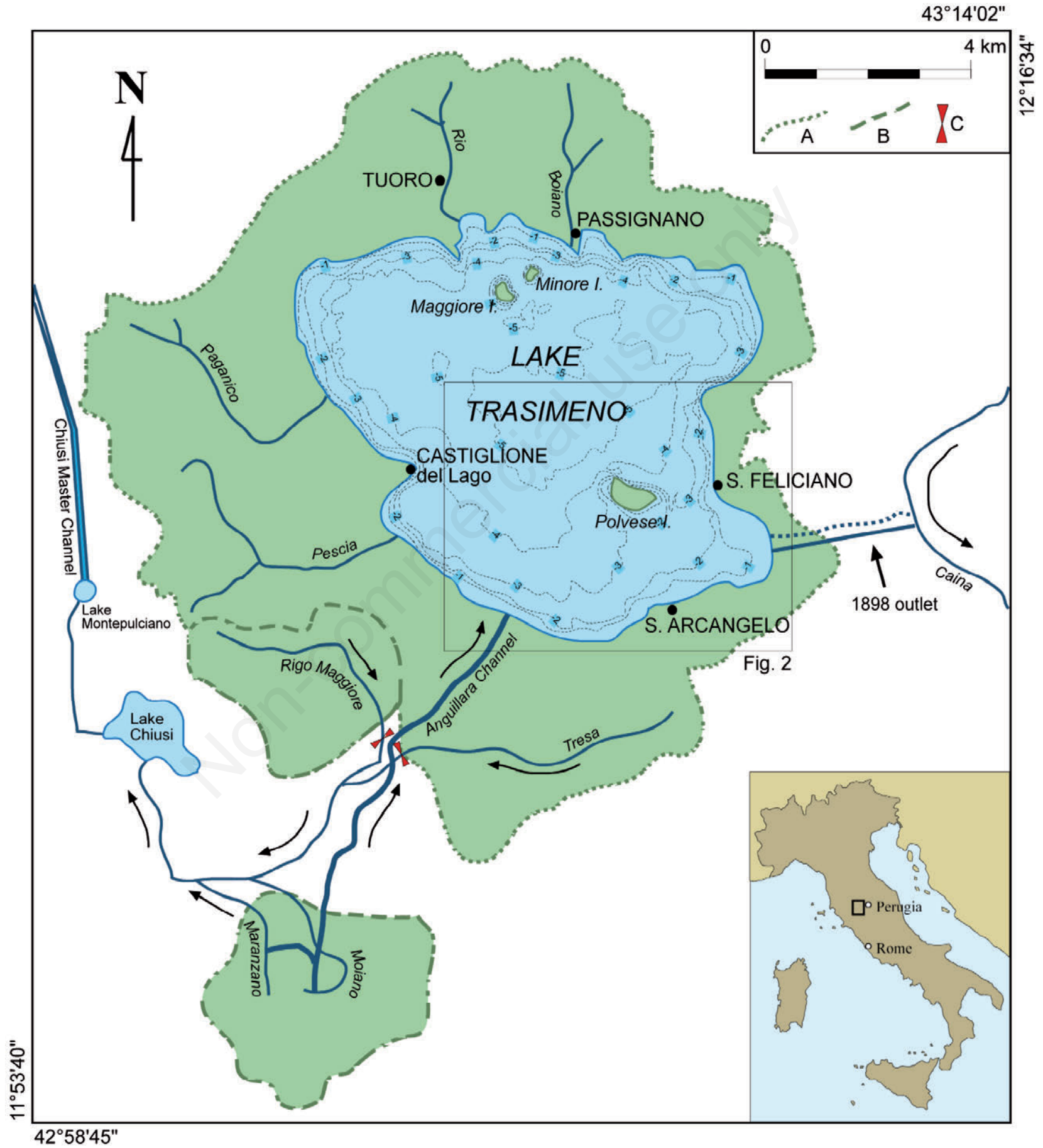

Fig. 1. Geographic location of the Trasimeno Lake. A, Natural catchment area; B, artificially-joined basins; C, sluice gates of the artificially-joined channels. Redrawn and modified from Fig. 4 (page 73) and Fig. 2 (page 125) in A. Martinelli (ed.), Tutela ambientale del Lago Trasimeno. Libri Arpa Umbria, Perugia, 2012 (with permission). 
2012), a mineral that usually adsorbs heavy metals and organic matter (Charavgis et al., 2012). According to Morgantini and Peruzzi (2012), the sediments have a content of organic matter (OM) up to 4\%, mainly of algal origin as shown by the TOC/ $\mathrm{N}_{\text {tot }}$ ratio ranging between 4 and 8 .

Recent studies on environmental conservation of Lake Trasimeno have shown that the lake is a relevant site for plant communities characterized by a good biodiversity level (Venanzoni et al., 2006). Aquatic macrophytes cover around $25 \%$ of the lake surface, particularly in the coastal zones, while the central pelagic area is devoid of aquatic vegetation due to the water turbidity and increasing water depth preventing its development (Havens et al., 2009). However, historical data indicate that the distribution of the hydrophyte and helophyte vegetation has greatly fluctuated depending on the lake level (Havens et al., 2009). During the low lake level of the so-called 1944-1960 'crisis', the entire lake area was populated by aquatic macrophytes belonging to genera Potamogeton, Myriophyllum and Chara, whilst riverbed communities dominated by Phragmites australis expanded in the lakeshore area. On the contrary, during the lake level high stand of the $1960 \mathrm{~s}$, the aquatic vegetation was reduced $\sim 30 \%$ (Havens et al., 2009) and riverbed communities were restricted to the emerged areas. Due to human impact and increased agricultural activities, a decrease in the macrophyte biodiversity was noticed between 1960s and 2007 (Charavgis et al., 2012). Phytoplankton blooms mainly composed by dinoflagellates, diatoms and cyanobacteria, this latter group dominating since 1992, underlines the rather high trophic level of the lake (Havens et al., 2009; Elia et al., 2012).

\section{Sampling and data collection}

During July 2014, a sampling campaign was carried out along the southern and south-eastern shores of Lake Trasimeno and on a N-S transect starting approximately from the middle of the lake $(2.5 \mathrm{~km}$ north of Island

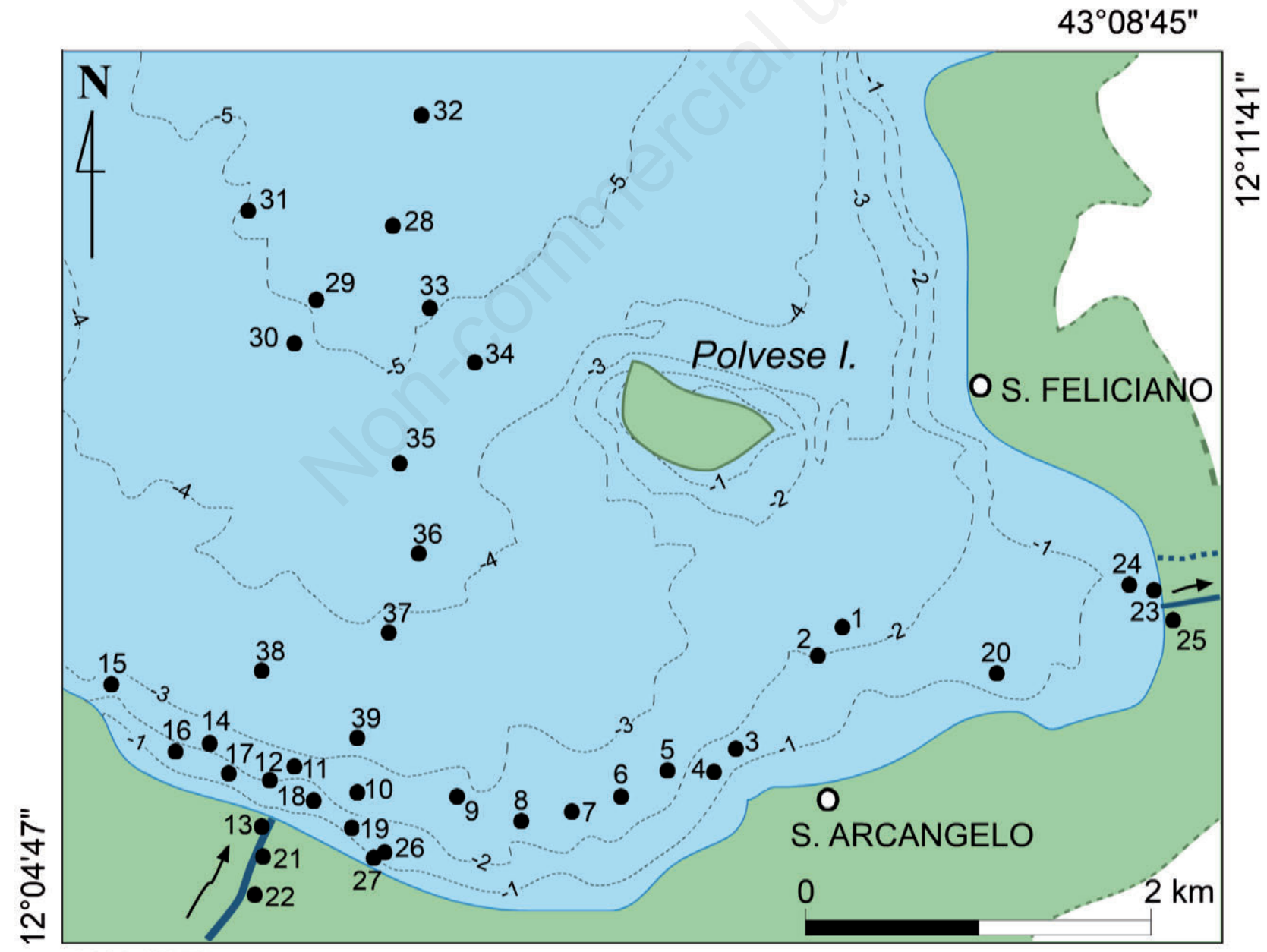

$43^{\circ} 04^{\prime} 35^{\prime \prime}$

Fig. 2. Geographical location of sampling sites. 
Polvese) towards the coast in front of the Anguillara Channel (Fig. 2). This area is of particular interest because it includes both the inflow and outflow channels, a relatively high anthropogenic pressure on the lakeshores (villages and cultivated fields and hills), and encloses the deepest part of the lake. In the field, the sample sites were roughly divided in two sets: sites deeper than $300 \mathrm{~cm}$, distant from the lakeshore and characterised by few macrophytes, and sites shallower than $300 \mathrm{~cm}$, apparently characterised by a quite variable range of bottom sediment and more or less abundant macrophytes.

Forty samples from the uppermost sediments $(4 \mathrm{~cm})$ were collected by scuba-diving using a rectangular handnet ( $28 \mathrm{~cm}$ x $14 \mathrm{~cm}, 120 \mu \mathrm{m}$ mesh size) (Tab. 1). One surface water sample was collected among free-floating macrophytes with a sampling bottle. In the field, samples were preserved in $75 \%$ ethanol and stained with Rose Bengal for 36-50 h, to differentiate living (or recently died) from sub-Recent ostracods (Walton, 1952; Bernhard et al., 2006). They were washed in the laboratory with tab water through a $125 \mu \mathrm{m}$-mesh sieve, dried and observed under a stereomicroscope for ostracod identification on the base of the shell features of adult specimens. Gonzalez Mozo et al. (1996), Meisch (2000) and Fuhrmann (2012) were followed for taxonomic identification.

While Rose Bengal staining is widely adopted in foraminifer studies, the method is not as commonly used by ostracodologists and sometimes its results have been questioned (Browers et al., 2000). Our results in the ostracode samples of Lake Trasimeno show that the staining is not reliable to discriminate between living and sub-Recent specimens. In the present study, we have considered as living (or recently died) specimens, stained or not stained, those with preserved appendages or setae on the shell surface. On this basis, the density of each species (expressed by individuals per $1 \mathrm{dm}^{2}$ ) was counted after identification.

All macrophytes were listed at each ostracod sampling station and their coverage was further estimated, as percentages, in the field. Different collection methods were used: floating masses of filamentous macroalgae were collected by means of a $25 \mu \mathrm{m}$-mesh plankton net; epilithic algae by scraping submerged stones; vascular plants by direct observation in situ or collecting samples using a grappling iron. All macroalgae were fixed in formalin (4\% was the approximate final concentration). Taxonomical determination and nomenclature were based on specific algae (John et al., 2002) and vascular plants literature (Pignatti, 1982; Conti et al., 2005).

During the sampling, physical and chemical parameters of the lake water such as temperature $\left(\mathrm{T},{ }^{\circ} \mathrm{C}\right)$, dissolved oxygen content (DO, $\left.\mathrm{mg} \mathrm{L}^{-1}\right)$, conductivity $(\mathrm{C}, \mu \mathrm{S}$ $\mathrm{cm}^{-1}$ ), Total Dissolved Solids (TDS, $\mathrm{g} \mathrm{L}^{-1}$ ) and $\mathrm{pH}$ were measured, using a Hydrolab Minisonde 4a multi-parame- ter instrument. Water depth $(\mathrm{D}, \mathrm{cm})$ was measured with a graduated rope. The concentration of major anions, cations and alkalinity $\left(\mathrm{HCO}_{3}{ }^{1-}+\mathrm{CO}_{3}{ }^{2-}\right)$ were measured on two water samples collected near the bottom at sites 1 and 28, following standard methods by LabService s.r.l (Anguillara Sabazia, RM, Italy).

A visual estimation of the grain size and other components, such as plant remains and mollusc shell fragments, was made to get qualitative analyses of the substrate. The presence of abundant plant detritus (from few millimeters to few centimeters in size), persistent even after a $\mathrm{H}_{2} \mathrm{O}_{2}$ treatment, prevented us to perform standard grain size analyses based on the weight of the different size fractions. Laser grain size analyses particularly adapted for the finest fraction were not performed due to the abundance of particles greater than $0.7 \mathrm{~mm}$.

Rock-Eval Pyrolysis has been used for characterizing the amount and nature of the organic matter of the bottom sediment. This method provides a good estimation of total organic carbon (TOC) and its quality based on the hydrogen and oxygen indices (Tissot and Welte, 1984; Peters, 1986; Meyers and Lallies-Vergès, 1999). It was initially used to study the hydrocarbon potential of petroleum source rocks (Espitalié et al., 1985) and nowadays it is also used in limnogeological studies (Ariztegui et al., 2001; Steinmann et al., 2003). A small amount of lake bottom sediments (ca. $0.45-0.55 \mathrm{mg}$ ) was pyrolysed (starts isothermally at $300^{\circ} \mathrm{C}$ and after heated to $650^{\circ} \mathrm{C}$ ) and completely oxidized (starts isothermally at $400^{\circ} \mathrm{C}$ and heated up to $850^{\circ} \mathrm{C}$ ). Following the alternative Rock-Eval method of Steinmann et al. (2003) for organic matter from recent lake sediments, four peaks were measured during the organic carbon decomposition: $\mathrm{S} 1$ (during the $300^{\circ} \mathrm{C}$ isotherm), S2a (between 300 $400^{\circ} \mathrm{C}$, peaking at ca. $365^{\circ} \mathrm{C}$ ), S $\mathrm{b}$ (above $400^{\circ} \mathrm{C}$, peaking at ca. $\left.465^{\circ} \mathrm{C}\right)$ and $\mathrm{S} 3\left(\mathrm{CO}_{2}\right.$ released above $\left.400^{\circ} \mathrm{C}\right)$. The total amount of residual and pyrolysed organic carbon corresponds to TOC. The S2/TOC ratio or Hydrogen index (HI) and the S3/TOC or Oxygen index (OI) represent the $\mathrm{H} / \mathrm{C}$ and the $\mathrm{O} / \mathrm{C}$ ratios of the organic matter, respectively (Espitalié et al., 1985). These two parameters allow separating different sources of organic matter (Ariztegui et al., 2001; Steinmann et al., 2003).

\section{Statistical analyses}

The collected data were processed through multivariate analyses using different algorithms: Non Metric Dimensional Scaling (NMDS), Canonical Correspondence Analysis (CCA), and the Spearman's rank correlation test using the PAST software, ver. 2.17b (Hammer et al., 2001). Three matrices have been used to perform multivariate analyses, using as respondents the sample sites and as variables the density (percentage of individuals $\mathrm{dm}^{-2}$ ) of each taxa in each sample, including a minimum $2 \%$ density. In the first matrix the physical and chemical pa- 


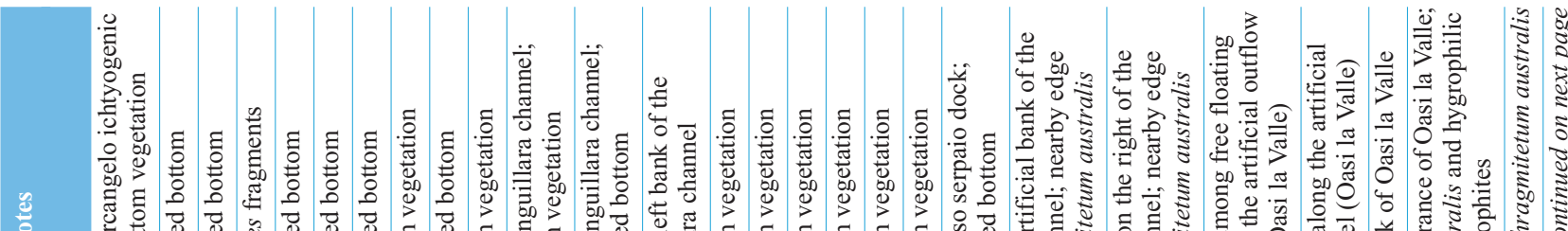

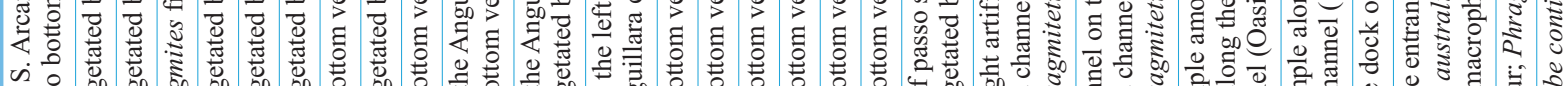

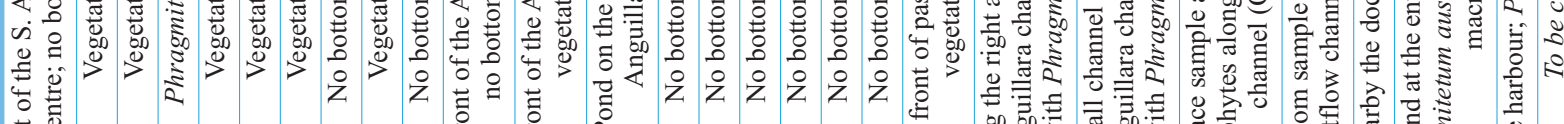 总 影

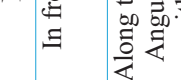

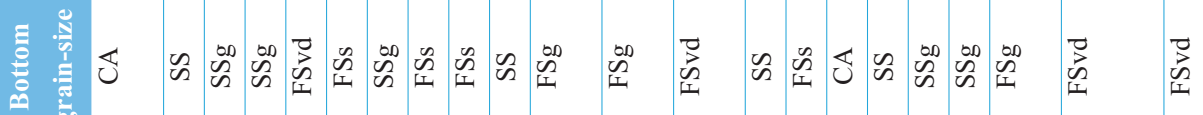

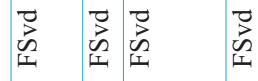

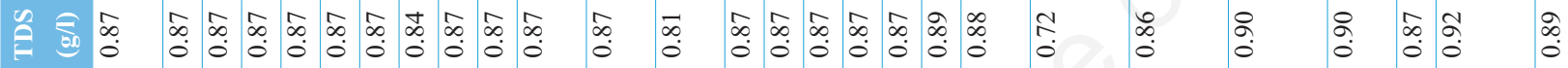

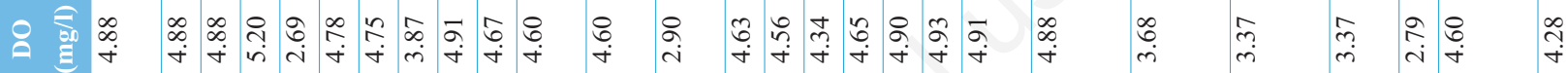

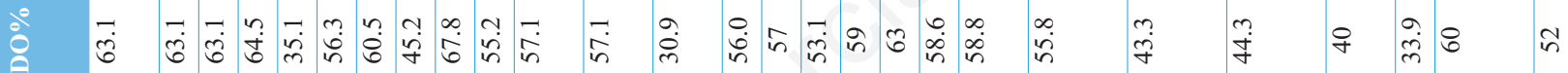

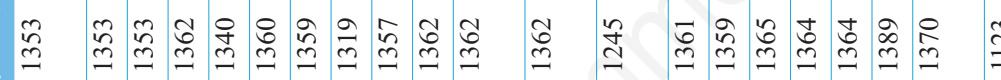

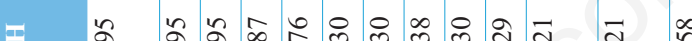
กิ

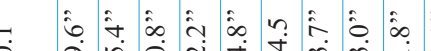

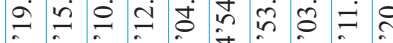

\section{b.}




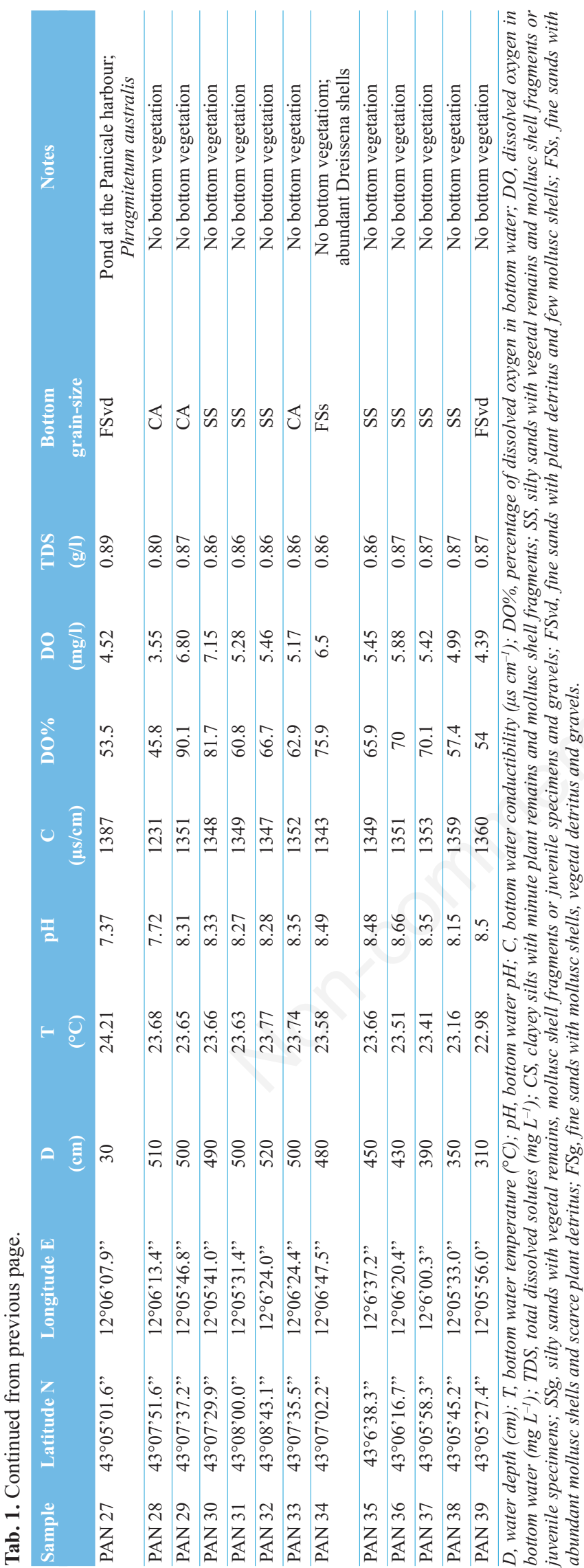

rameters measured at each sampling station (depth, TDS, $\mathrm{T}, \mathrm{DO}, \mathrm{pH}, \mathrm{TOC})$, bottom grain size (GR) and macrophytes (mac) were added to the variables. This matrix was used to run the NMDS using Euclidean distance in Qmode (samples) and the Canonical Correspondence Analysis (CCA) in R-mode (species). The variables of the second matrix data include the ostracod densities and the frequencies of each identified macrophyte species. The variables of the third matrix data are the ostracod densities and the different type of substratum. The Correlation test using Spearman's rank index was applied to these matrices, to identify a relation among the different data sets.

\section{RESULTS}

\section{Physical and chemical parameters of the water}

During summer 2014 and for the first time since 1988, Lake Trasimeno held a water level above the hydrometric zero. Indeed, the lake level was $+12 \mathrm{~cm}$, while in the previous years it was $-41 \mathrm{~cm}$ (2013) and $-133 \mathrm{~cm}$ (2012) with a maximum drawdown of $-142 \mathrm{~cm}$ recorded in 2008 (data from Club Velico Trasimeno, http://www.clubvelicotrasimeno.it/livellolago.aspx). This high lake level was linked to particularly high rainfall conditions which affected the Lake Trasimeno hydrographic basin during 2014, corresponding to a annual rainfall of $940 \mathrm{~mm}$ (Perugia Province, unpublished data) in comparison with the mean annual rainfall of 700-800 mm/year for the 1963-2014 period (Valigi et al., 2016).

The physical and chemical parameters measured at each sampling site are reported in Tab. 1. Bottom water temperatures display small variations, being the differences between the distal (deepest) area and the lakeshore zone not greater than $3^{\circ} \mathrm{C}$, ranging from 22 to $25^{\circ} \mathrm{C}$. Conductivity and TDS are rather homogeneous, 1123 to 1442 $\mu \mathrm{S} \mathrm{cm}{ }^{-1}$, and 0.7 to $0.9 \mathrm{~g} \mathrm{~L}^{-1}$, respectively; $\mathrm{pH}$ values are more variable, from 6.9 to 8.7 , as well as the dissolved oxygen content at the bottom that varies from 2.69 to 7.15 $\mathrm{mg} \mathrm{L}^{-1}$. According to the results reported in Tab. 2 the water of Lake Trasimeno can be defined as chlorine, sulphate-calcium and magnesium-rich. Because of the present high stand conditions of the lake, the measured chlorine concentration is lower in comparison with the values of the last twenty years (5.78 vs 6.06-8.98 $\mathrm{m}^{2} \mathrm{~L}^{-1}$, respectively), although the conductivity values are only

Tab. 2. Water chemical analyses $\left(\mathrm{m}^{2} \mathrm{~L}\right)$.

\begin{tabular}{lccccccc} 
Samples & $\mathrm{Cl}^{-}$ & $\mathrm{Alk}$ & $\mathrm{SO}_{4}^{-}$ & $\mathrm{Ca}^{++}$ & $\mathrm{Mg}^{++}$ & $\mathrm{K}^{+}$ & $\mathrm{Na}^{+}$ \\
PAN 1 & 5.78 & 1.88 & 0.94 & 0.6 & 2.96 & 0.13 & 0.81 \\
\hline PAN 28 & 6.52 & 1.79 & 0.92 & 1.42 & 1.86 & 0.18 & 0.84 \\
\hline Alk, total alkalinity. & & & & & &
\end{tabular}


slightly lower (1231-1442 vs $1440 \mu \mathrm{S} \mathrm{cm}^{-1}$ during 2005) (Ludovisi and Gaino, 2010).

\section{Bottom sediment features}

Sediment texture along with the amount and type of organic matter $(\mathrm{OM})$ have been investigated in all sampling sites. They contain fine sediments (clays, silts, fine sands) with some coarser elements such as plant detritus, shells (or shell fragments) and gravels. Six different kind of substrates were distinguished based on visual observations of the bottom sediments: CS, clayey silts with few plant remains and mollusc shell fragments; SS, silty sands with vegetal remains and mollusc shell fragments or juvenile specimens; $\mathrm{SSg}$, silty sands with vegetal remains, mollusc shell fragments or juvenile specimens and gravels; FSvd,- fine sands with vegetal detritus and few mollusc shells; FSs, fine sands with abundant mollusc shells and scarce plant detritus; FSg, fine sands with mollusc shells, vegetal detritus and gravels (Tab. 1).

CS and SS substrates are mainly located in the center of the lake, in the deeper zone, except for samples 10, 14, and 17; substrates SSg and FSg are typical of lakeshore areas; FSvd is found in vegetated lakeshore zones; and FSs is recognizable mainly around depths of $240-270 \mathrm{~cm}$ except for the deep site $34(480 \mathrm{~cm})$. TOC ranges from 0.36 to $10.21 \%$ of sample weight, but most of the samples varied between 1.90 to $2.40 \%$. OI ranges between 127 and $329 \mathrm{mg} \mathrm{CO}_{2} \mathrm{~g}^{-1}$ and $\mathrm{HI}$ between 144 and $744 \mathrm{mg} \mathrm{Hc} \mathrm{g}^{-1}$. Using a Van Krevelen-type plot it is possible to separate different types of organic matter and therefore their sources (Fig. 3a). Three types of organic matter are identified (Meyers and Lallies-Vergès, 1999): Type I (micro- bial biomass or waxy coatings of land plants), Type II (algae) and Type III (woody plant matter). HI decreases whereas OI increases from Type I to III. As shown in Figs. $3 \mathrm{a}$ and $3 \mathrm{~b}$, almost all samples from Lake Trasimeno are grouped around Type II and Type III, i.e., the organic carbon present in the bottom sediments derives from both algae and terrestrial plants. Some exceptional samples, PAN 14 and PAN 9, show relatively higher values indicating higher algal content and plotting close to the Type I field.

\section{Ostracod assemblages}

Thirty-eight out of the forty-one collected samples contained living ostracod assemblages. The composition and density of the ostracod coenoses recorded during our campaign corresponds to high-stand conditions $(+12 \mathrm{~cm}$ above the hydrometric zero). On the whole, nineteen species were recognized (Figs. 4 and 5). Darwinula stevensoni (Brady and Robertson, 1870), Candona (Candona) candida (O.F. Müller, 1776), Candona (Neglecandona) angulata G.W. Müller, 1900, Fabaeformiscandona fabaeformis (Fischer, 1850), Pseudocandona marchica (Hartwig, 1899), Cypria ophtalmica (Jurine, 1820), Ilyocypris gibba (Ramdohr, 1808), I. salebrosa Stepanaitys, 1959, I. getica Masi, 1905, Cypridopsis vidua (O.F. Müller, 1776), Eucypris virens (Jurine, 1820), Trajancypris clavata (Baird, 1838), Herpetocypris helenae G.W. Müller, 1908, Heterocypris salina (Brady, 1868), Heterocypris incongruens (Ramdohr, 1808), Isocypris beauchampi (Paris, 1920), Cyprideis torosa (Jones, 1850), Limnocythere inopinata (Baird, 1843), and Limnocythere stationis Vavra, 1891 were represented by living individuals. Moreover, only loose valves of Potamo-
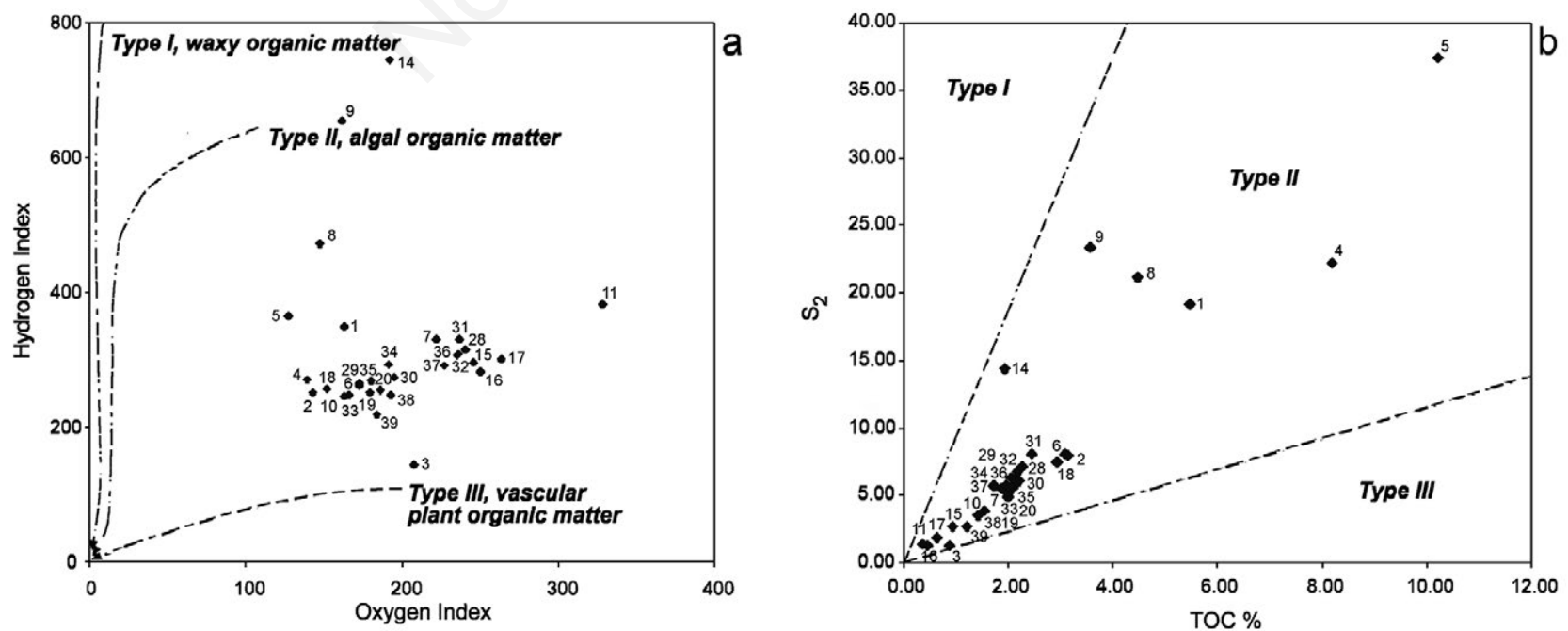

Fig. 3. a) Van Krevelen-type diagram for Lake Trasimeno sedimentary organic matter; dots represent samples and dashed lines trace the maturity paths for organic matter types. b) S2 vs TOC diagram. Dashed lines define the boundaries of organic matter types. 
cypris variegata (Brady and Norman, 1889) and Fabaeformiscandona harmsworthi (Scott, 1899) were recovered, thus these species are not considered as living in the lake.
Several carapaces and valves of $H$. helenae were collected in the lake. The valve outline is slightly different from the typical outline of the species illustrated by Gon-

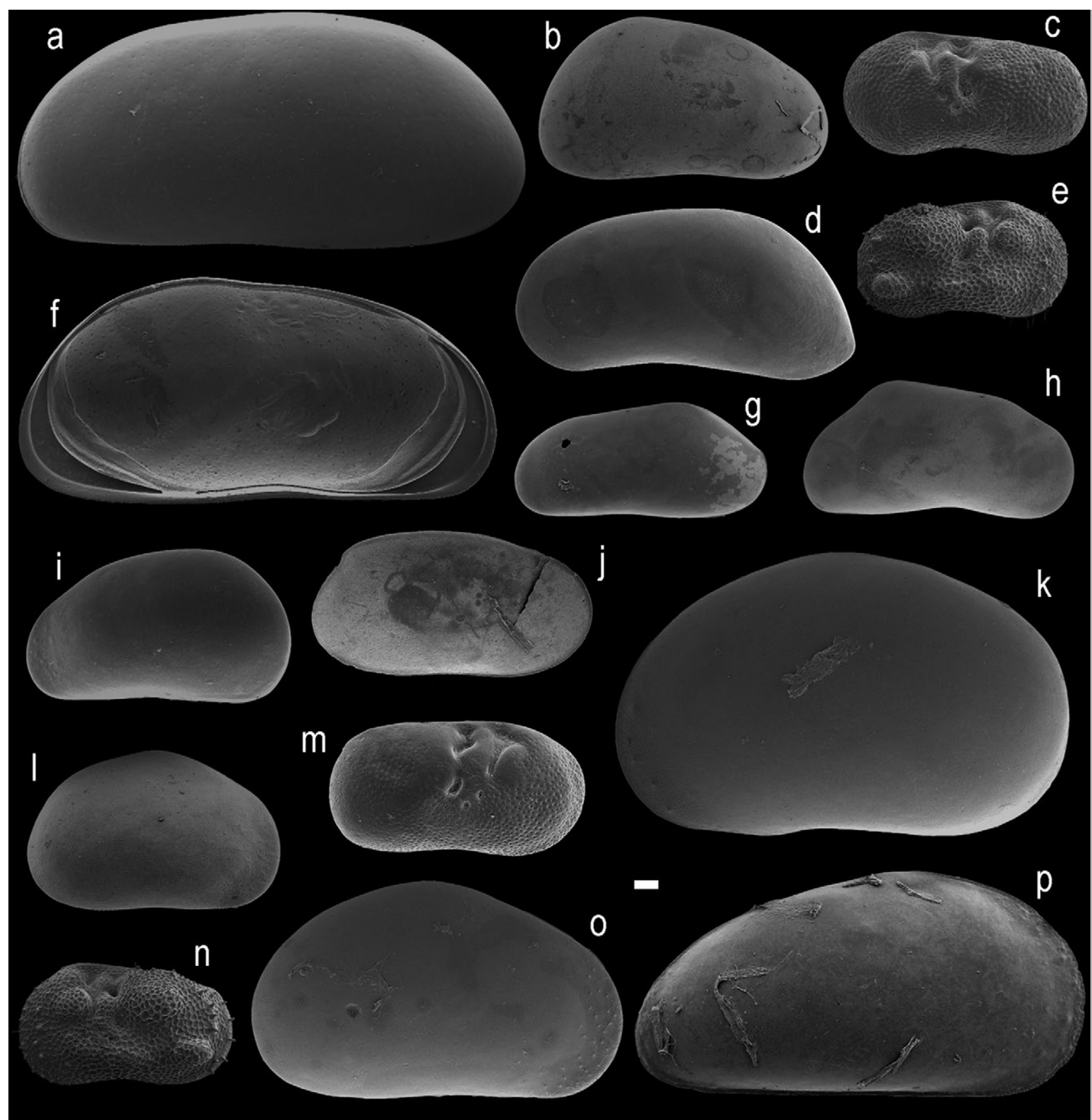

Fig. 4. SEM photos of the living ostracods from Lake Trasimeno. a. Herpetocypris helenae, female LV, sample PAN 11; b. Candona (Candona) candida, female RV, sample PAN 23bot; c. Ilyocypris gibba, female LV, sample PAN 6; d. Candona (Neglecandona) angulata, female LV, sample PAN 38; e. Ilyocypris salebrosa, female RV, sample PAN 11; f. Herpetocypris helenae, LV, inner view, sample PAN 11; g. Fabaeformiscandona fabaeformis, female LV, sample PAN 3; h. Fabaeformiscandona harmsworthi, male (?) RV, sample PAN 24; i. Pseudocandona marchica, female LV, sample PAN 39; j. Isocypris beauchampi, female RV, sample 35, slightly damaged anteriorly and posteriorly; k. Eucypris virens, female LV, sample PAN 39; 1. Heterocypris salina, female RV, sample PAN 11; m. Ilyocypris getica, female RV, sample PAN 9; n. Ilyocypris salebrosa, female LV, sample PAN 11; o. Heterocypris incongruens, female RV, sample PAN 11; p. Trajancypris clavata, female RV, sample PAN 11. LV, left valve; RV, right valve; C, carapace. White bar corresponds to 0.1 mm. 
zalez Mozo et al. (1996) and Fuhrmann (2012), with the dorsal margin slightly inclined forward rather than horizontal. Conversely, the features visible on the inner margin are comparable. Masi (1909), describing the valves of 'Cypria intermedia var. latialis' from the surroundings of Rome and Sicily, remarked that the dorsal border was faintly inclined forwards. Masi's variety is considered synonym of $H$. helenae by Pieri et al. (2015). Thus, we consider this slightly different feature to fall within the morphological variability of $H$. helenae.
Except 10 samples in which only loose valves or very few carapaces were recovered (samples 1, 13, 14, 16, 19, 20, 21, 21bis, 22, 27), all the other samples displayed abundant carapaces and valves (from 50 to 500 specimens including instars). C. torosa, C. vidua, C. (N.) angulata, and $L$. inopinata are the most abundant species. They are represented by several adult carapaces $(271,87,78$, and 53, respectively) and hundreds of loose valves. Except for the asexual $C$. vidua, L. inopinata is represented only by female specimens whereas the other two species were rep-

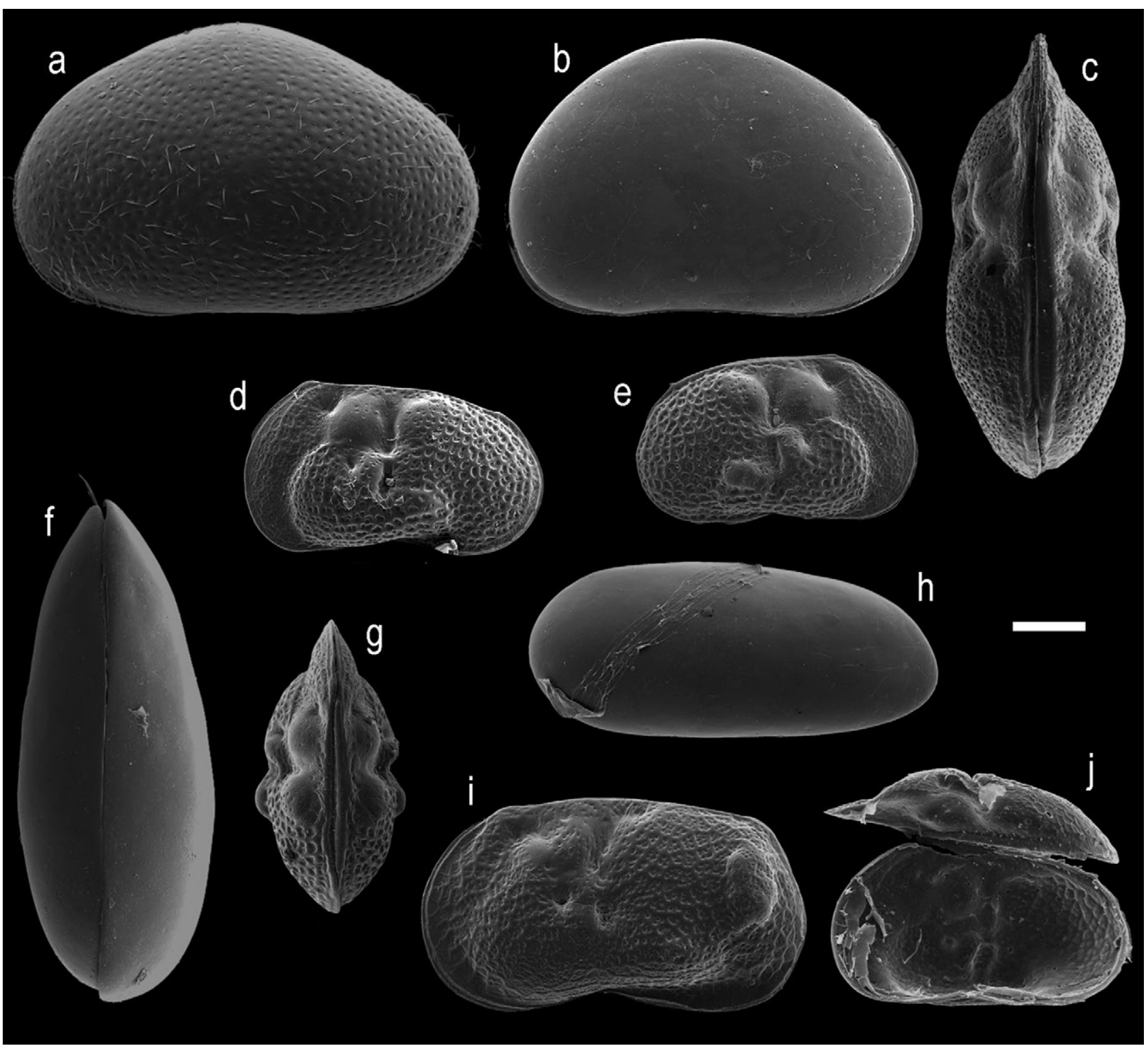

Fig. 5. SEM photos of the living ostracods from Lake Trasimeno. a. Cypridopsis vidua, female LV, sample PAN 13; b. female Cypria ophtalmica, RV, sample PAN 23bot; c. Limnocythere inopinata, female C, dorsal view, sample PAN 2; d. Limnocythere stationis, female LV, sample PAN 5; e. female Limnocythere stationis, RV, sample PAN 5; f. Darwinula stevensoni, female C, dorsal view, sample PAN 3; g. Limnocythere stationis, female C, dorsal view, PAN 5; h. Darwinula stevensoni, female RV, sample PAN 6; i. Limnocythere inopinata, female LV, sample PAN 10; j. Limnocythere stationis, open female C with appendage remains, sample PAN 6. Abbreviations as in Fig. 6. White bar corresponds to $0.1 \mathrm{~mm}$. 
resented both by males and females with the following sex female/male ratios (calculated on the recovered carapaces): C. torosa 6:5 and C. (N.) angulata 3:1.

These dominant species have been recovered in the bottom samples of the lake with densities reaching maximum values of 25.0 (C. torosa), 12.2 (C. vidua), 6.3 (C. (N.) angulata), and 36.8 (L. inopinata) individuals $\mathrm{dm}^{-2}$.

The remaining species occur only in few samples. Carapaces, adult loose valves and juveniles were recovered except for I. beauchampi, T. clavata and E. virens that were represented by only 1-3 valves.

\section{Macrophytes assemblages}

Macrophytes were identified in twenty-one out of the forty-one sampling stations. Species richness ranges from one to nine different taxa. The absence of macrophytes is in correspondence with the deepest stations in the central zone of the lake and with turbid waters. A total of 17 macrophyte taxa (ten flowering plants, seven algae) were recorded, among which the most common were Phragmites australis (Cavanilles) Trinius ex Steudel, Najas marina Linnaeus, Ceratophyllum demersum Linnaeus, Potamogeton perfoliatus Linnaeus and Vallisneria spiralis Linnaeus. The first three species were also the most abundant locally. Communities characterized by $P$. australis were prevalent along and strictly close to the banks, while those dominated by $N$. marina or $C$. demersum were the more widespread in the lake.

Ostracods were found in all sampling stations with aquatic vegetation. They were either in the substrate among the vegetation or, less often, attached to it.

\section{Ostracod communities, macrophytes and substrate}

The NMDS plot (Fig. 6) related to the first matrix, shows the distribution of the sampling sites depending on their physical and chemical, sedimentological and biological parameters. The dots in the Shepard plot appear strongly aligned; the very low value of stress (0.056) and the consequent very high nonlinear fit $\left(\mathrm{R}^{2}=0.997\right)$ confirm the rejection of the null model $\left(\mathrm{R}^{2}=0\right)$, where all the observations 'fall in the same point'.

The sample distribution in the plot illustrates the different ecological niches recognized in the study area. Samples characterised by depths below $300 \mathrm{~cm}$ are all grouped in the upper portion of the diagram. They share $\mathrm{pH}$ values between 7.7 and 8.7, absence of macrophytes, fine substrate, and ostracod assemblages $(C$. $(N$.) angulata-C. torosa assemblage) and display a rather wide range of DO values (3.55-6.80 $\left.\mathrm{mg} \mathrm{L}^{-1}\right)$. Conversely, samples with depth above $300 \mathrm{~cm}$ are more scattered in the

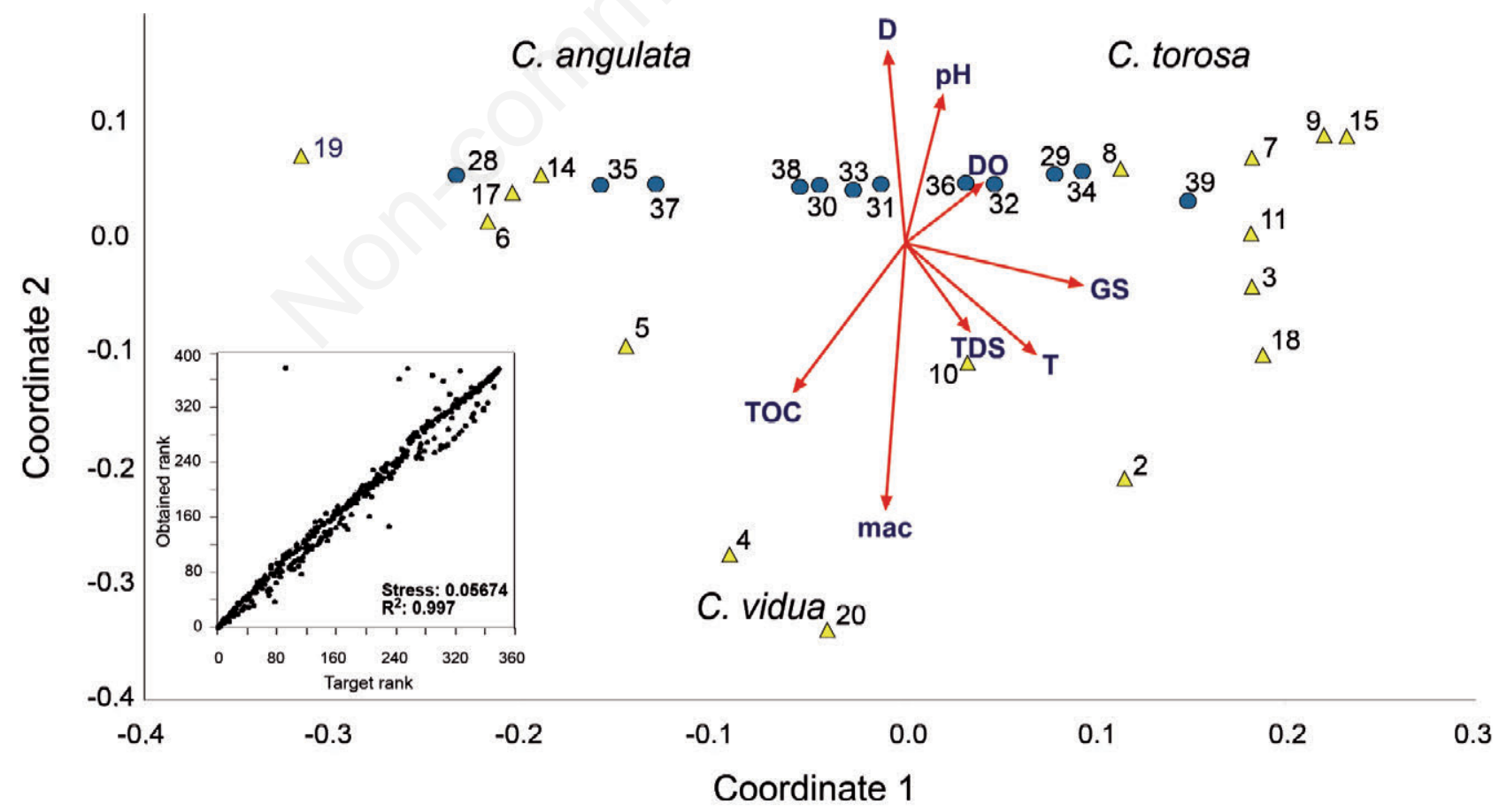

Fig. 6. Non-Metric Multidimensional Scaling (NMDS) ordination plot for sampling sites (circle, deep samples; triangles, lakeshore samples), abiotic parameters (D, water depth; DO, dissolved oxygen in bottom water; GS, bottom grain size; $\mathrm{pH}$, bottom water $\mathrm{pH}$; $\mathrm{T}$, bottom water temperature; TDS, total dissolved solutes; TOC, total organic carbon), and macrophytes (mac) (Euclidean similarity measure). The Shepard plot is shown on the left lower corner. The dominant species of each sample group are also reported in the plot. 
diagram, showing a plurality of niches. Some samples located in the upper part of the plot $(6,14,17,19$ on the left and $7,8,9,11,15$ on the right) are devoid or contain scarce macrophytes. They are separated in two different groups, due to the different dominance of ostracod species, with $C$. (N.) angulata and C. torosa prevailing in the groups on the left and on the right, respectively. Other shallow samples, in the lower part of the plot, are strongly influenced by TOC and macrophytes abundance (5, 4 and 20 ), with samples 4 and 20 characterized by the dominance of $C$. vidua and sample 5 by $C$. (N.) angulata. Additional parameters influencing this distribution are oxygen depletion and substrate features that enclose silty sands, plant detritus, shells and gravels.

The Canonical Correspondence Analysis plot (Fig. 7), also related to the first matrix, shows the relationship between physical and chemical parameters and ostracod species. Axes 1 represents $61.22 \%$ of the total variance. A Monte Carlo permutation test (999 permutations) allowed for rejecting $(\mathrm{P}<0.01)$ the null hypothesis of nonsignificant gradients on the first axis (ter Braak and Verdonshot, 1995). The first axis separates the species on the base of the macrophytes occurrence (regression coefficient 0.78 ) and TOC (regression coefficient 0.50 ) and, to a lesser extent, depth (regression coefficient -0.48) and $\mathrm{pH}(-0.41)$ gradients. C. vidua, D. stevensoni and C. oph- talmica correlate positively with macrophytes and TOC whereas they correlate negatively with depth and $\mathrm{pH} . H$. helenae. $H$. salina and $H$. incongruens display a strong correlation to depth and $\mathrm{pH}$.

The Spearman's rank values with $\mathrm{P}<0.001$ show that $P$. australis is the macrophyte species with the highest correlation with ostracods displaying a moderate positive correlation with $H$. helenae $(\mathrm{rho}=0.51121)$ and $C$. vidua $(\mathrm{rho}=0.55081)$ and a moderate negative correlation with C. torosa $($ rho $=-0.5423)$. Moderate positive correlations are also observed between $C$. demersum and $L$. inopinata $($ rho $=0.50615)$. Finally, a very strong positive correlation $($ rho $=1)$ has been identified between Potamogeton natans Linnaeus and L. stationis.

For the substratum type, the Spearman's rank values with $\mathrm{P}<0.001$ show that $H$. salina strongly correlates with fine sands containing plant detritus, shells and gravels (rho $=0.66009)$.

\section{DISCUSSION}

Living ostracod assemblages have been seldom investigated in Italian lakes. Some information on ostracods are reported for Lake Maggiore (Fox, 1965), Ragogna (Colizza et al., 1987), Mantova (Melis et al., 1995, 1996; Salvi

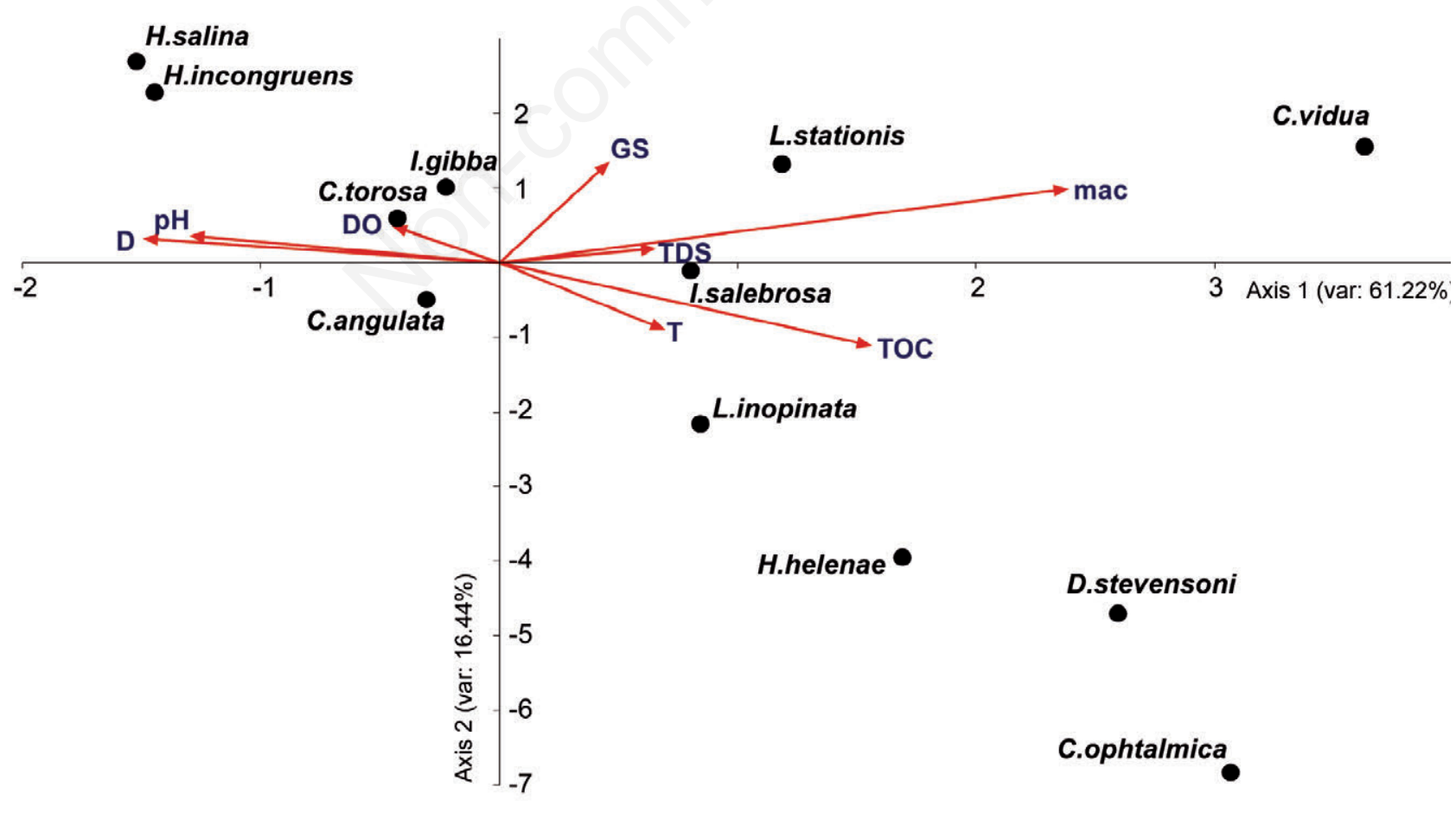

Fig. 7. Canonical Correspondence Analysis (CCA) ordination plot for ostracods, abiotic parameters (D, water depth; DO, dissolved oxygen in bottom water; GS, bottom grain size; $\mathrm{pH}$, bottom water $\mathrm{pH}$; T, bottom water temperature; TDS, total dissolved solids; TOC, total organic carbon), and macrophytes (mac) in the space defined by the first two canonical axes (77.66\% eigenvalue). 
and Degrassi, 1995), Bracciano (Mastrantuono, 1995), and Martignano (Mastrantuono and Mancinelli, 2003). Additionally, Pieri et al. (2015) reported ostracods from some small mountain lakes in Piedmont, the Dolomites (northern Italy) and the central Apennines (Abruzzo Region). However, only few of these studies analyse the presence of ostracods in their environment, linking their assemblages with the dominant physical, chemical and biological conditions. Moreover, the relationship between ostracods, macrophytes and the substrate is poorly investigated in Italian freshwater systems (Mazzini et al., 2014b) despite the definition of such links could be extremely useful to identify former ecological niches and habitat (Matsuda et al., 2015).

Little is known about the ostracods of Lake Trasimeno. Von Hartmann (1964) pointed out the presence of living $C$. torosa and, more generally, the occurrence of ostracods has been signaled in several articles dealing with the diet of fishes inhabiting the lake and crucial for the local economy (Mantilacci et al., 1990). Meisch (1985) recovered few valves of $P$. variegata from an irrigation channel near Lake Trasimeno.

The 19 species collected among the living meiobenthos of Lake Trasimeno are widely recorded in other Italian freshwater or brackish sites (Pieri et al., 2015) but three of them (C. torosa, I. salebrosa, L. stationis) deserve an in-depth discussion.

C. torosa is widespread in Eurasia and Africa (Wouters, 2002) in marine-derived brackish waters of marginal environments or water bodies influenced by the sea. However, Van Harten (1990) defined the species as anomalohaline due to its ability to adapt also to athalassic waters. In fact, records of this species in athalassic waters were reported by Klie (1938) from Germany (Gruber See, Bavaria; Trammer See, Plön), and thermal waters in Iceland, while Mezquita et al. (1999) recorded it in freshwater-oligohaline springs in eastern Spain. The identification of $C$. torosa in Lake Trasimeno further confirms this statement. Neale (1988) and Griffiths and Holmes (2000) reported a very wide salinity range $0.4-150 \mathrm{~g} \mathrm{~L}^{-1}$ for $C$. torosa, with specimens displaying rather large size and developing noded shells below the osmoregulation threshold of $8 \mathrm{~g} \mathrm{~L}^{-1}$ (Van Harten, 1996, 2000; Keyser and Aladin, 2004; Keyser, 2005; Boomer and Frenzel, 2011; Frenzel et al., 2012). As already observed by von Hartmann (1964), in our samples C. torosa shells from Lake Trasimeno are mostly noded (69\%), but on some valves nodes are barely visible or totally absent. Following Sandberg's notation (1964), in our specimens we typically observed well-developed nodes 1, 2 and 3, whereas nodes 2a, 5 and 6 are often visible, and nodes 4 and 7 are very rarely present (Fig. 8). Nodes are also present on instars, starting from the A-3 moult. Concerning the size, on average the specimens of Lake Trasimeno are slightly larger than those reported by Decima (1964) for a marginal marine population of $C$. torosa recovered at Forte dei Marmi (Tuscany, Italy) (average length of the female right valve $1.03 \mathrm{~mm}$ vs $0.92 \mathrm{~mm}$ and average length of the male left valve $1.17 \mathrm{~mm}$ vs $1.00 \mathrm{~mm}$, respectively).

I. salebrosa in Lake Trasimeno is the southernmost appearance of this species in Italy. Mazzini et al. (2014b) and Pieri et al. (2015) reported it only from northern Italy (Lombardia and Emilia-Romagna regions). More generally, Italy is the Eurasian westernmost country in which this species occurs. Up to now it has been described from lakes Biwa and Okinawa in Japan (Schornikov, 2004; Smith et al., 2011), lakes Bosten and Taihu in China (Mischke, 2001; Mischke and Schudack, 2001, shells only; Yu et al., 2005), in Korea (Lee et al., 2000), in India as Ilyocypris shawneetownensis (Bhatia and Singh, 1971; Mischke, 2001), and in Thrace Turkey (Özuluğ, 2005). Smith et al. (2011) consider Pelocypris alatobulbosa Delorme, 1970 from Canada synonim of I. salebrosa and suspects its presence also in Serbia, quoted by Karan-Žnidaršič and Petrov (2007) under the name Ilyocypris decipiens.

Living specimens of $L$. stationis were previously found in Italy only at Cà Nuova rice-field (Lombardia, northern Italy; Moroni and McKenzie, 2007). Because this species has not been previously reported in the Italian fossil record, these authors considered it as part of the 'foreign guest' contingent that was introduced by man in Italy with the trial strains of seed rice or other cereals coming from abroad and/or in dust associated with trade goods. However, recently L. stationis has been recovered in the fossil record of the Panicarola borehole (south Lake Trasimeno onshore), possibly aged Early-Middle Pleistocene (Marchegiano, personal communication) and from Holocene boreholes drilled in Gorgo Basso and Lake Preola (Trapani, Sicily) (Curry et al., 2013) thus, although rare, this species must be considered part of the Italian ostracod fauna. Outside Italy, the species has been reported in Eurasia, particularly in France (Paris, 1920), Austria (Löffler, 1971), Germany (Wohlgemuth, 1914; Fuhrmann and Pietrzeniuk, 1990; Fuhrmann, 2012), Macedonia (Petkovski, 1964), Finland (Meisch, 2000), Russia (Schornikov, 2004), Turkey (Altınsaçl1, 2001), Israel [Mischke et al., 2012 (shells only)], Jordania [Mischke et al., 2012 (shells only)], Yemen [Mohammed et al. (2014) (shells only)], Sudan (Martens, 1984), China (Schornikov, 2004), Japan (Smith and Janz, 2009), Thailand (Savatenalinton, 2014), and Korea (Lee et al., 2000).

$C$. torosa and $C$. (N.) angulata are the most frequent species in the lake. These halophilic species are mainly found in marginal marine environments (Meisch, 2000; Fuhrmann, 2012). Their frequency and abundance in Lake Trasimeno could be explained by the chemistry of the lake waters which are rich in chlorine and sodium (Charavgis et al., 2012). According to Ludovisi and Gaino (2010) this 
peculiar chemical composition is due to the geology of the catchment area and the watershed flowing in the lake that is rich in these ions as a consequence of weathering processes or wastewater discharges. The groundwater hydrogeochemistry of the Trasimeno area shows that the aquifers linked to alluvial and Plio-Pleistocene sediments are mainly alkaline-earth bicarbonate or chloride alkaline sulphate in nature. Analogously, the deep aquifers settled in Miocene turbidites are enriched in chloride and alkaline-earth bicarbonate due to the dissolution of chlorides or the incongruent dissolution of aluminosilicates (plagioclase and K-feldspar) (ARPA Umbria, 2005). Tiberi (1980) excluded a significant exchange between groundwater and lake waters but ARPA Umbria (2005) estimated a groundwater contribution of ca. 2.43-3.64 $\mathrm{Mm}^{3}$ year ${ }^{-1}$. The latter would represent around $2.5 \%$ of the total water supplied to the water body by rainfall and surficial runoff and would be enough to drive the chemical composition of the lake.

$C$. torosa and C. (N.) angulata have been recovered both in the distal part of the lake and in the lakeshore area. As shown in the NMDS and CCA plots (Figs. 6 and 7) in both cases these species are associated with scarce or absent macrophytes and low TOC values. The alternate dominance of these two species in the distal deeper assemblages seems to be linked mainly to bottom water oxygen availability: $C$. (N.) angulata dominates in the most oxygen-depleted sediments (3.55-5.45 $\left.\mathrm{mg} \mathrm{L}^{-1}\right)$ while C. torosa becomes dominant with higher oxygen values (5.46-6.80 $\mathrm{mg} \mathrm{L}^{-1}$ ). The former is rather surprising although the tolerance range for dissolved oxygen of $C$. (N.) angulata is not known (Ruiz et al., 2013). Indeed, previous work shows that this species generally occurs in oxygenated waters from 9.20 to $22.8 \mathrm{mg} \mathrm{L}^{-1}$ (Martin et al., 1993; Akdemir, 2008; Özuluğ, 2012; Altınsaçlı, 2014). On the contrary, C. torosa is known for its ability to survive also in depleted oxygen environments until hypoxia (Jahn et al., 1996; Mesquita-Joanes et al., 2012).

Although $C$. torosa and $C$. (N.) angulata sometimes are the dominant species also in samples from shallow lakeshore areas, they are often accompanied by other species such as $C$. vidua that become frequent in very shallow to shallow $(20-140 \mathrm{~cm})$ sites with high TOC, macrophytes and algae (samples in the low left quarter of NMDS plot, Fig. 6). It is known that $C$. vidua is a phytophilic species that prefers abundant plant coverage containing macrophytes as well as algae (Characeae) (Meisch, 2000). In Lake Trasimeno this species correlates strongly with the

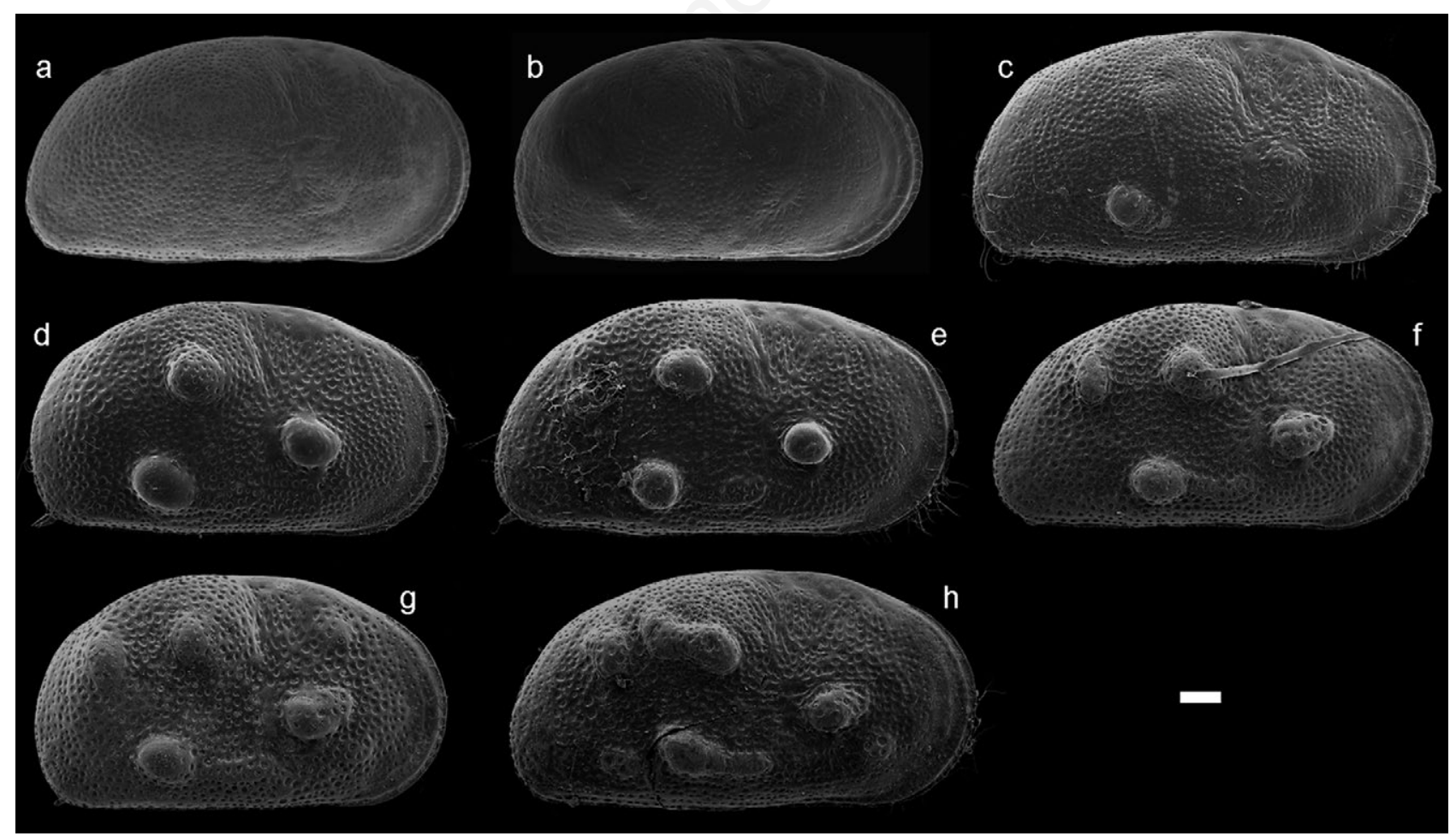

Fig. 8. SEM photos of Cyprideis torosa from Lake Trasimeno. a. Male RV, un-noded; b. Female RV, un-noded; c. male RV, node 2; d. female RV, nodes 1, 2, 3; e. male RV, nodes 1, 2, 2a, 3; f. male RV, nodes 1, 2, 2a, 3, 6; g. female RV, nodes 1, 2, 2a, 3, 4, 6; h. male RV, nodes 1, 2, 2a, 3, 5, 6, 7. Abbreviations as in Fig. 6. White bar corresponds to $0.1 \mathrm{~mm}$. 
presence of vegetation (Figs. 6 and 7) and we found only this species (mainly instars) among the roots of free-floating plants as S. polyrrhiza, L. minor and L. trisulca, while, at the bottom of the same site, adults of this species are accompanied by $C$. ophtalmica and $C$. (C.) candida. The same has been recognized by Kiss (2007) at Lake Fehér (Hungary). It is particularly interesting to confirm the strict relation between some species and free-floating macrophytes, already recognized by Kiss (2007) and Mazzini et al. (2014a). L. inopinata dominates areas with low presence of $C$. torosa and $C$. (N.) angulata, slightly deeper (around 150-210 cm) (samples in the low right quarter of the NMDS plot, Fig. 6). It seems to prefer less vegetate bottoms. Despite the ability of this species to adapt to several environmental conditions (Meisch, 2000), in Lake Trasimeno it shows a moderate correlation to $\mathrm{T}$ (Fig. 7) suggesting that it could be a polythermophilic species.

The rest of the ostracod species occur in few samples and represents a subordinate component of the ostracod assemblage, except for H. helenae, I. salebrosa, and H. incongruens that could be locally dominant. The first species represents up to $67 \%$ of the ostracod fauna in a very shallow $(20 \mathrm{~cm})$ lakeshore pond densely populated by $P$. australis. It is accompanied by I. gibba $(20 \%)$ and I. salebrosa (13\%). I. salebrosa reaches $57 \%$ of the ostracod community (accompanied by H. salina and H. incongruens) in a 200 $\mathrm{cm}$ deep pond lateral to the inflow of the Anguillara Channel, rich in algae (pennate and centric diatoms, Cladophora glomerata Linnaeus, Oedogonium sp. and Spyrogyra sp.) and with moderate $P$. australis coverage. $H$. incongruens reaches $25 \%$ of an assemblage dominated by $C$. vidua (75\%) along the cemented banks of the Anguillara Channel, nearby its inflow in the lake, in very shallow conditions ( 20 $\mathrm{cm}$ ) and rather coarse bottom with macrophyte allochtonous remains and pebbles. The ecology of $H$. helenae and H. incongruens is rather well known (Meisch, 2000; Fuhrmann, 2012) and their presence in the described environments does not record any additional autoecological data. Conversely, I. salebrosa ecology is relatively unknown. In Lake Biwa (Japan) it has been collected at water depths ranging from 5.5 to $16 \mathrm{~m}$ (Smith et al., 2011), while in Turkish lakes in the Thracia region occurs at rather high temperatures $\left(24.6-30^{\circ} \mathrm{C}\right), \mathrm{pH}(8.0-8.8)$ and, at least at Lake Gala, it was found with $V$. spiralis and Myrophyllum spicatum Linnaeus (Özuluğ, 2005). In Lake Trasimeno I. salebrosa has been collected at shallower depths ( 0.2 to $2.5 \mathrm{~m}$ ), slightly lower $\mathrm{pH}$ (7.6-8.3), and comparable temperatures $\left(24.4-25.3^{\circ} \mathrm{C}\right)$. Furthermore, it seems that it tolerates rather low oxygen content (DO 2.9-5.2 $\mathrm{mg} \mathrm{L}^{-1)}$, and oligohaline waters (TDS $0.80-0.87 \mathrm{~g} \mathrm{~L}^{-1}$ ). Only in one sample it is associated with $P$. australis and in another samples with abundant diatoms.

The results of the multivariate analyses indicate that the central and southern areas of Lake Trasimeno enclose several ecological niches. The main parameters affecting the ostracod assemblages are the macrophyte coverage, TOC and, to a lesser extent, depth and $\mathrm{pH}$.

The changes in macrophyte covers is clearly influenced by sediment characteristics, as well as hydrodinamism and underwater irradiance (Van Duin et al., 2001). In Trasimeno, the deepest part of the lake has a dominant clay substrate and a complete absence of macrophytes, they colonize lakeshore areas encompassing coarser sediments. Phragmites australis communities dominate the southwestern coast, nearby the Anguillara Channel, while aquatic macrophytes (Potamogeton spp., $V$. spiralis, Najas spp. and C. demersum) are frequent along the southeastern coast.

The TOC values obtained by Rock-Eval Pyrolysis mirrors the macrophyte distribution, being higher along the coast (except for the most western sector) and decreasing towards the distal part of the lake. This is in agreement with the TOC distribution previously reported by Morgantini and Peruzzi (2012) indicating the highest TOC values in the southeastern shoreline and the lowest contents in the southwestern area. Intermediate values (around 2\%) were recorded in the central (deepest) part of the lake. The differences recorded on the TOC distribution could be linked to multiple, complex processes, also occurring outside the lake. For instance, land use changes can affect the input of nutrients in the inflowing rivers and thus can lead to changes in lake productivity that subsequently alter the TOC burial in the sediment (Sifeddine et al., 2011). The linkage between macrophyte distribution and TOC is also shown by the HI and OI that clearly suggest a mixed source of allochtonous (plant material such as vascular plants) and autochtonous organic matter (algal type such as phytoplancton). Based on TOC/ $\mathrm{N}_{\text {tot }}$ ratios, Morgantini and Peruzzi (2012) ascribed an algal origin to this sedimentary organic matter. Most likely, these differences in interpretation are due to the use of different analytical methods. As suggested by Meyers (1997) TOC/ $\mathrm{N}_{\text {tot }}$ ratios can be affected by the presence of clay-rich sediments ('matrix effect') that adsorb ammonium ions $\left(\mathrm{NH}_{4}{ }^{+}\right)$causing a decrease of this ratio. The latter is coherent with the high OI values obtained by Rock-Eval and explain the mixed character of the $\mathrm{OM}$ as shown in the Van Krevelen plot of Fig. 3.

\section{CONCLUSIONS}

The living ostracod fauna of the shallow endorheic Lake Trasimeno has been investigated for the first time. Within the 19 species identified, several assemblages have been recognized, related to different ecological niches distinguished on the basis of the physical and chemical water parameters as well as different type of substratum and macrophytes coverage, confirming once 
more the strong ties between ostracods and their host environment. Although no endemic taxa have been identified in the lake, the occurrence of the three species $C$. torosa, I. salebrosa, and L. stationis addresses several issues related to biodiversity and (palaeo)-limnology. In particular, the occurrence of C. torosa, living in an inland lake with low salinity waters, highlights the need of a cautious palaeoenvironmental interpretation when this species occurs in older records. A careful observation of the shell morphology must be carried out especially when this is the dominant species. The occurrence of I. salebrosa expands the distribution area of the species to central Italy, with consequences on its meaning within the Mutual Ostracod Temperature Range applications (Horne, 2007). L. stationis has been considered for a long time an alien species, disseminated by passive transport in the rice fields of Northern Italy. As a matter of fact, the occurrence of fossil representatives in Umbria and Sicily and the occurrence of this species living in present Lake Trasimeno, could tell a completely different story, linked to loss of habitats and lack of specific studies more than to freshwater invasions as previously thought.

The knowledge of the present-day ostracod population of Lake Trasimeno represents a further tessera in the mosaic of the distribution of ostracods in Italian inland waters. It provides a starting point to evaluate both past and present climate- and anthropogenically-induced changes of this fragile environment.

\section{ACKNOWLEDGMENTS}

The ostracod and macrophyte sampling at Lake Trasimeno was carried out with the authorisation of the Perugia Province (Servizio Difesa e Gestione Idraulica dell'Area Ambiente e Territorio) and we are grateful to Ing. Gianluca Paggi. We wish to thank Dr. Umberto Pessolano for his help during the sampling activities and the Cooperativa Pescatori del Trasimeno, particularly its President Mr. Aurelio Cocchini and Mr. Alessandro Angeli, for providing the boat during the sampling campaign of July 2014. We are indebted with Dr. Sergio Lo Mastro for the SEM pictures of ostracods. This work was funded by the Department of Science, University Roma Tre. Furthermore, we wish to thank Dave Horne and Tadeusz Namiotko for the fruitful discussion on $F$. harmsworthi. The comments and suggestions of two anonymous referees greatly helped us to improve this manuscript.

\section{REFERENCES}

Akdemir D, 2008. Differences in Ostracoda (Crustacea) Assemblages between Two Maar Lakes and One Sinkhole Lake in the Konya Region of Turkey. Turkish J. Zool. 32:107-113. Altınsaçlı S, 2001. The Ostracoda (Crustacea) Fauna of Lakes Erikli, Hamam, Mert, Pedina and Saka (Üûneada, Kirklareli, Turkey). Turkish J. Zool. 25:343-355.

Altınsaçlı S, 2014. Species diversity and distribution of Ostracoda (Crustacea) in mesosaline Lake Bafa (Aegean Region, Turkey). J. Entol. Zool. Studies 2. 2:16-32.

Ariztegui D, Chondrogianni C, Lami A, Guilizzoni P, Lafargue E, 2001. Lacustrine organic matter and Holocene palaeoenvironmental record of Lake Albano (central Italy). J. Palaeolimn. 26:283-892.

Ataniyazova OA, 2003. Health and ecological consequences of the Aral Sea Crisis, p. 1-6. In: Proceedings 3rd World Water Forum Regional Cooperation in Shared Water Resources in Central Asia, Kyoto.

ARPA Umbria, 2005. [Gli acquiferi nel bacino del Lago Trasimeno: analisi delle caratteristiche idrogeologiche e idrogeochimiche per la valutazione dei rapporti con il corpo idrico lacustre e l'identificazione di criticità ambientali].[Report in Italian]. Monografia/5, Regione Umbria.

Bernhard JM, Ostermann DR, Williams DS, Blanks JK, 2006. Comparison of two methods to identify live benthic foraminifera: A test between Rose Bengal and CellTracker Green with implications for stable isotope paleoreconstructions. Paleoceanography 21:1-8.

Bhatia SB, Singh D, 1971. Ecology and distribution of some Recent ostracodes of the Vale of Kashmir, India. Micropaleontology 17:214-220.

Boomer I, Frenzel P, 2011. Possible environmental and biological control on carapace size in Cyprideis torosa (Jones, 1850). Joannea Geol. Paläontol. 11:26-27.

Boomer I, Wharley R, Aladin NV, 1996. Aral Sea Ostracoda as environmental indicators. Lethaia 29:77-85.

Browers EM, Cronin TM, Horne DJ, Lord AR, 2000. Recent shallow marine ostracods from high latitudes: implications for late Pliocene and Quaternary palaeoclimatology. Boreas 29:127-143.

Charavgis F, Ciccarelli E, Cingolani L, Di Brizio M, Morgantini N, Notargiacomo T, Renzi S, Todini B, 2012. [Quadro delle conoscenze ambientali pregresse, p. 43-68]. In: A. Martinelli (eds.), [Tutela ambientale del Lago Trasimeno].[Book in Italian]. Libri Arpa Umbria, Perugia.

Colizza E, Fanzutti GP, Pugliese N, 1987. The diffusion of ostracode fauna in Lake Ragogna (Friuli, Italy). Biogeographia 8:529-537.

Conti F, Abbate G, Alessandrini A, Blasi C, 2005. An annoted checklist of Italian flora. Palombi editori, Roma.

Curry B, Mesquita-Joanes F, Fanta S, Sterner D, Calò C, Tinner W, 2013. Two coastal sinkhole lakes in SW Sicily (Italy) reveal low-salinity excursion during Greek and Roman occupation. Nat. Sic. 37:93-95.

Decima A, 1964. [Ostracodi del Gen. Cyprideis Jones del Neogene e del Quaternario italiani].[Article in Italian]. Palaeontograph. Ital. 57:81-133.

Dragoni W, Melillo M, Giontella C, 2012. [Bilancio idrico del lago Trasimeno p. 69-85]. In: A. Martinelli (eds.), [Tutela ambientale del Lago Trasimeno].[Book in Italian]. Libri Arpa Umbria, Perugia.

Elia AC, Todini C, Di Brizio M, Taticchi MI, 2012. 4. [Struttura e composizione del popolamento fitoplanctonico del Lago 
Trasimeno negli ultimi cinquanta anni p. 89-99]. In: A. Martinelli (eds.), [Tutela ambientale del Lago Trasimeno].[Book in Italian]. Libri Arpa Umbria, Perugia.

Espitalié J, Deroo G, Marquis F, 1985. [La pyrolise Rock-Eval et ses applications].[Article in French]. Rev. Inst. Fr. Pét. 40:563-579.

Fox HM, 1965. The ostracods of the Lago Maggiore. Mem. Ist. Ital. Idrobiol. 19:81-89.

Frenzel P, Schulze I, Pint A, 2012. Noding of Cyprideis torosa valves (Ostracoda) - a proxy for salinity? New data from field observations and a long-term microcosm experiment. Int. Rev. Hydrobiol. 97:314-329.

Fuhrmann R, 2012. [Atlas quartärer und rezenter Ostrakoden Mitteldeutschlands].[Book in German]. Altenburger Naturwissenschaftliche Forschungen. 15. Mauritianum, Altenburger.

Fuhrmann R, Pietrzeniuk E, 1990. [Die Ostracodenfauna des Interglazials von Gröbern (Kreis Grafenhainichen), p. 168193]. In: L. Eissman (eds.), [Die Eemzeit und die frühe Weichselszeit im Saale-Elbe-Gebiet: Geologie, Paläontologie, Paläökologie].[Book in German]. Altenburger narurwissenschaftliche Forrschungen, 5. Mauritianum, Altenburg.

Gallinaro N, Tavernini S, Cantoni F, 2014. Project EULAKES Ref. Nr. 2CE243P3 European Lakes under Environmental Stressors (Supporting lake governance to mitigate the impact of climate change). Final Report. Comunità del Garda: $149 \mathrm{pp}$.

Gasperini L, Barchi MR, Bellucci LG, Bortoluzzi G, Ligi M, Pauselli C, 2010. Tectonostratigraphy of Lake Trasimeno (Italy) and the geological evolution of the Northern Apennines. Tectonophysics 492:164-174.

Gonzalez Mozo ME, Martens K, Baltanas A, 1996. A taxonomic revision of European Herpetocypris Brady and Norman, 1889 (Crustacea, Ostracoda). Bull. Inst. R. Sci. Nat. Belg. Biologie 66:93-132.

Griffiths HI, Holmes JA, 2000. Non-marine ostracods adn Quaternary palaeoenvironments. Quat. Res. Ass. Tech. Guides 8:1-179.

Hammer Ø, Harper DAT, Ryan PD, 2001. PAST, paleontological statistics software package for education and data analysis. Palaeontol. Electron. 4:1-9.

Havens KE, Elia AC, Taticchi MI, Fulton III RS, 2009. Zooplankton-phytoplankton relationships in shallow subtropical versus temperate lakes Apopka (Florida, USA) and Trasimeno (Umbria, Italy). Hydrobiologia 628:165-175.

Helfert M, Holz R, 1985. Multi-source verification ofthe desiccation of Lake Chad, Africa. Adv. Space Res. 5:379-384.

Horne DJ, 2007. A mutual temperature range method for Quaternary palaeoclimatic analysis using European non-marine Ostracoda. Quat. Sci. Rev. 26:1398-1415.

Jahn A, Gamenick I, Theede H, 1996. Physiological adaptations of Cyprideis torosa (Crustacea, Ostracoda) to hydrogen sulphide. Mar. Ecol. Prog. Ser. 142:215-223.

John DM,Whitton BA, Brook AJ, 2002. The freshwater algal flora of the British Isles. Cambridge University Press, Cambridge.

Karan-Žnidaršič T, Petrov B, 2007. Non-marine Ostracoda (Crustacea) of Banat district in Serbia. Hydrobiologia 585:57-66.

Keyser D, 2005. Histological peculiarities of the nodin process in Cyprideis torosa (Jones) (Crustacea, Ostracoda). Hydrobiologia 538:95-106.

Keyser D, Aladin NV, 2004. Noding in Cyprideis torosa and its causes. Stud. Quat. 21:19-24.

Kiss A, 2007. Factors affecting spatial and temporal distribution of Ostracoda assemblages in different macrophyte habitats of a shallow lake (Lake Fehér, Hungary). Hydrobiologia 585:89-98

Klie W, 1938. [Die Tierwelt Deutschlands und der angrenzenden Meeresteile nach ihren Merkmalen und nach ihrer Lebensweise: Krebstiere oder Crustacea III: Ostracoda, Muschelkrebse].[Book in German]. Gustav Fischer Verlag, Jena.

Lauwaet D, van Lipzig NPM, Van Weverberg K, De Ridder K, Goyens C, 2012. The precipitation response to the desiccation of Lake Chad. Quart. J. Meteorol. Soc. 138:707-719.

Lee E, Huh M, Schornikov EI, 2000. [Ostracod fauna from the East Sea coast of Korea and their distribution - preliminary study on Ostracoda as an indicator of water pollution].[Article in Korean with English abstract]. J. Geol. Soc. Korea 36:435-472.

Löffler H, 1971. [Daten zur subfossilen und lebenden Ostracodenfauna in Wörthersee und Klopeiner See. Carinthia 2].[Article in German]. Mitt. Nat. Land. Kärn. Sonderheft 31:79-89.

Löffler H, 1990. [Paleolimnology of Neusiedlersee, Austria. I. The succession of ostracods. Hydrobiologia 214:229-238.

Ludovisi A, Gaino E, 2010. Meteorological and water quality changes in Lake Trasimeno (Umbria, Italy) during the last fifty years. J. Limnol. 69:174-188.

Mantilacci L, Mearelli M, Giovinazzo G, Lorenzoni M, 1990. [Accrescimento e alimentazione del latterino (Atherina boyeri Risso) del lago Trasimeno].[Article in Italian]. Riv. Idrobiol. 29:309-327.

Martens K, 1984. On the freshwater ostracods (Crustacea, Ostracoda) of the Sudan, with special reference to the Red Sea Hills, including a description of a new species. Hydrobiologia 110:137-161.

Martin DS, Shine AJ, Duncan A, 1993. The profundal fauna of Loch Ness and Loch Morar. Scott. Nat. 105:119-133.

Martinelli A, 2012. [Tutela ambientale del Lago Trasimeno]. [Book in Italian]. Libri Arpa Umbria, Perugia.

Masi L, 1909. [Descrizione di alcune Cypridae italiane].[Article in Italian]. Arch. Zool. Ital. 3:347-407.

Mastrantuono L, 1995. Composition and structure of the invertebrate fauna in littoral sandy shores of Lake Bracciano (central Italy) and water quality monitoring. Limnetica 11:17-27.

Mastrantuono L, Mancinelli T, 2003. Meio-Macrobenthic invertebrates associated with submerged vegetation in a CharaLake (Lake Martignano, Italy). Atti Ass. Ital. Oceanol. Limnol. 16:187-201.

Matsuda JT, Lansac-Tôha FA, Martens K, Machado Velho LF, Mormul RP, Higuti J, 2015. Association of body size and behavior of freshwater ostracods (Crustacea, Ostracoda) with aquatic macrophytes. Aquat. Ecol. 49:321-331.

Mazzini I, Ceschin S, Abati S, Gliozzi E, Piccari F, Rossi A, 2014a. Ostracod communities associated to aquatic macrophytes in an urban park in Rome, Italy. Int. Rev. Hydrobiol. 99:1-10.

Mazzini I, Gliozzi E, Rossetti G, Pieri V, 2014b. The Ilyocypris 
puzzle: A multidisciplinary approach to the study of phenotypic variability. Int. Rev. Hydrobiol. 99:1-14.

Meisch CK, 1985. Revision of the recent west European species of the genus Potamocypris (Crustacea, Ostracoda). Part II Species with long swimming setae on the second antennae. Trav. Sci. Mus. Natl. Hist. Nat. Luxemb. 6:1-95.

Meisch CK, 2000. Freshwater ostracoda of western and central Europe. Spektrum Akademischer Verlag, Heidelberg.

Melis R, Pugliese N, Degrassi C, 1995. [Ostracofauna del Lago di Mezzo e del Lago Inferiore (Mantova, LombardiaItalia)].[Article in Italian]. Atti Mus. Geol. Paleontol. Monfalcone 3:65-70.

Melis R, Pugliese N, Salvi G, 1996. Ostracoda of the Lago Superiore of Mantova (Lombardia, Italy), p. 185-190. In: M. Keen (ed.), Proceedings 2nd European Ostracodologists Meet. Glasgow, Scotland. British Micropaleontological Society, London.

Mesquita-Joanes F, Smith AJ, Viehberg FA, 2012. The ecology of Ostracoda across levels of biological organisation from individual to ecosystem: a review of recent developments and future potential, p. 15-35. In: D.J. Horne, J.A Holmes, J. Rodriguez Lazaro and F. Viehberg (eds.), Ostracoda as proxies for Quaternary climate change. Developments in Quaternary Science 17. Elsevier, Amsterdam.

Meyers PA, 1997. Organic geochemical proxies of paleoceanographic, paleolimnologic and paleoclimatic processes. Org. Geochem. 27:213-250.

Meyers PA, Lallier-Vergès E, 1999. Lacustrine sedimentary organic matter records of Late Quaternary palaeoclimates. J. Paleolimnol. 21:345-372.

Mezquita F, Hernández R, Rueda J, 1999. Ecology and distribution of ostracods in a polluted Mediterranean river, p. 87103. Palaeogeogr. Palaeoclimatol. Palaeoecol. 148:87-103.

Micklin, P, 2007. The Aral Sea disaster. Annu. Rev. Earth Planet. Sci. 35:47-72.

Mischke S, 2001. Mid and Late Holocene palaeoenvironment of the lakes Eastern Juyanze and Sogo Nur in NW China, based on ostracod species assemblages and shell chemistry. Berl. Geowiss. Abh. 35:1-131.

Mischke S, Schudack ME, 2001. Sub-recent Ostracoda from Bosten Lake, NW China. J. Micropalaeontol. 20:12.

Mischke S, Ginat H, Al-Saqarat B, Almogi-Labin A, 2012. Ostracods from water bodies in hyperarid Israel and Jordan as habitat and water chemistry indicators. Ecol. Indic.14:87-99.

Mohammed MA, Keyser D, Al-Wosabi MA, Al-Khirbash B, AlQadassi WM, 2014. Taxonomy and distribution of fresh water Ostracoda from Socotra Island, Yemen. Rev. Micropaleontol. 57:23-33.

Morgantini N, Peruzzi L, 2012. [La distribuzione di metalli, nutrienti e microinquinanti nei sedimenti recenti del Lago Trasimeno, p. 129-156]. In: A. Martinelli (eds.), [Tutela ambientale del Lago Trasimeno.[Book in Italian]. Libri Arpa Umbria, Perugia.

Moroni A, McKenzie KG, 2007. Ostracoda of the Italian ricefield ecosystems. Accademia Nazionale delle Scienze (detta dei XL), Roma.

Neale JV, 1988. Ostracods and paleosalinity reconstruction, p. 125-155. In: P. De Deckker, J.P. Colin and J.P. Peypouquet (eds.), Ostracoda in the earth sciences. Elsevier, Amsterdam.

Özuluğ O, 2005. Living specimens of Ilyocypris salebrosa
Stepanaitys, 1959 (Crustacea: Ostracoda) from Thrace, Turkey. Zool. Middle East 34:114-116.

Özuluğ O, 2012. The effect of dam construction on the Ostracoda (Crustacea) assemblage in Kazandere Stream, Thracea, Turkey. Pak. Jo. Zool. 44:635-639.

Paris P, 1920. [Notes sur le Cladocères et les Ostracodes du Département de la Côte-D’Or].[Article in French]. Bull. Soc. Zool. Fr. 44:251-266.

Peters KE, 1986. Guidelines for evaluating petroleum source rock using programmed pyrolisis. AAPG Bulletin 70:318-329.

Petkovski T, 1964. Bemerkenswerte Entomostraken aus Jugoslavien. Acta Mus. Maced. Sci. Nat. 9:147-182.

Pieri V, Martens K, Meisch C, Rossetti G, 2015. An annotated checklist of the Recent non-marine ostracods (Ostracoda: Crustacea) from Italy. Zootaxa 3919:271-305.

Pignatti S, 1982. [Flora d'Italia I-III].[Book in Italian]. Edagricole, Bologna.

Rodriguez-Lazaro J, Ruiz-Muñoz F, 2012. A general introduction to Ostracods: morphology, distribution, fossil record and applications, p. 1-14. In: D.J. Horne, J.A. Holmes, J. Rodriguez-Lazaro and F.A. Viehberg (eds.), Ostracoda as proxies for Quaternary climate change. Developments in Quaternary science 17. Elsevier, Amsterdam.

Ruiz F, Aba M, Bodergat AM, Carbonel P, Rodríguez-Lázaro J, González-Regalado ML, Toscano A, García EX, Prenda J, 2013. Freshwater ostracods as environmental tracers. Int. J. Environ. Sci. Technol. 10:1115-1128.

Salvi G, Degrassi C, 1995. [Rinvenimento di Metacypris cordata Brady \& Robertson, 1870 e Stenocypris major (Baird, 1859) nei laghi di Mantova (Lombardia, Italia)].[Article in Italian]. Atti Mus. Geol. Paleontol. Monfalcone 3:81-88.

Sandberg PA, 1964. The Ostracod genus Cyprideis in the Americas. Stock. Contrib. Geol. 12:1-178.

Savatenalinton S, 2014. Ostracods (Crustacea: Ostracoda) from the floodplain of the Chi River, Mahasarakham Province, Northeast Thailand, with the first record of male Tanycypris siamensis Savatenalinton \& Martens, 2009. Zootaxa 3838:195-206.

Schornikov E, 2004. Crustacea: Ostracoda, p. 458-465. In: A.N Tyurin and A.L. Drozdov (eds.), Far-Eastern marine biosphere reserve. 2. Dalnauka, Vladivostok.

Scott T, 1899. Report on the Marine and freshwater Crustacea from Franz-Josef Land collected by Mr. William S. Bruce of the Jackson-Hamsworth Expedition. J. Linn. Soc. London Zool. 27:60-126.

Shukla A, 2015. The shrinking of Aral Sea (a worst environmental disaster). Int. J. Inn. Appl. Stud. 11:633-643.

Sifeddine A, Meyers P, Cordeiro R, Albuquerque A, Bernardes M, Turcq B, Abrão J, 2011. Delivery and deposition of organic matter in surface sediments of Lagoa do Caçó (Brazil). J. Paleolimnol. 45:385-396.

Smith RJ, Jank H, 2009. Recent ostracods of the Superfamily Cytheroidea and Darwinuloidea (Crustacea) from Lake Biwa, a Japanese ancient lake. Species Diversity 14:217-241.

Smith RJ, Janz H, Okubo I, 2011. Recent Cyprididae and Ilyocyprididae (Crustacea: Ostracoda) from Lake Biwa, Japan, including a summary of the lake's ostracod fauna. Zootaxa 2874:1-37.

Soja G, Züger J, Knoflacher M, Kinner P, Soja AM, 2013. Climate impacts on water balance of a shallow steppe lake in 
Eastern Austria (Lake Neusiedl). J. Hydrol. 480:115-124.

Steinmann P, Adatte T, Lambert P, 2003. Recent changes in sedimentary organic matter from lake Neuchâtel (Swizerland) as traced by Rock-Eval pyrolysis. Ecl. Geol. Helv. 96:109-116.

Taticchi MI, 1992. Studies on Lake Trasimeno and other waterbodies in Umbria Region (central Italy), p. 295-317. In P. Guilizzoni, G. Tartari and G.Giussani (eds.), Limnology in Italy, Mem. Ist. Ital. Idrobiol., Pallanza.

ter Braak CJF, Verdonschot PFM, 1995. Canonical correspondence analysis and related multivariate methods in aquatic ecology. Aquat. Sci. 57:255-289.

Tiberi O, 1980. [Floruri e cloruri nel Lago Trasimeno].[Article in Italian]. Riv. Idrobiol. 19:37-60.

Tissot BP, Welte DH, 1984. Petroleum formation and occurrence. Springer-Verlag, Berlin.

Valigi D, Luque-Espinar JA, Di Matteo L, Cambi C, PardoIgúzquiza E, Rossi M, 2016. Analysis of drought conditions and their effects on Lake Trasimeno (Central Italy) levels. Ital. J. Groundwater. doi: http://dx.doi.org/10.7343/as-2016-215.

Van Duin EHS, Blom G, Los FJ, Maffione R, Zimmermann R, Cerco CF, Dortch M, Best EPH, 2001. Modeling underwater light climate in relation to sedimentation, resuspension, water quality and autotrophic growth. Hydrobiologia 444:25-42.

Van Harten D, 1990. The Neogene evolutionary radiation in Cyprideis Jones (Ostracoda: Cytheracea) in the Mediterranean Area and the Parathetys. Cour. Forsch-inst. Senckenberg 123:191-198.

Van Harten D, 1996. Cyprideis torosa (Ostracoda) revisited. Of salinity, nodes and shell size, p. 191-194. In: Proceedings 2nd European Ostracodologists, Glasgow, Scotland. British Micropalaeontological Society, London.

Van Harten D, 2000. Variable noding in Cyprideis torosa (Os- tracoda, Crustacea): an overview, experimental results and a model from Catastrophe Theory. In: D.J. Horne and K. Martens (eds.), Evolutionary biology and ecology of Ostracoda. Hydrobiologia 419:131-139.

Venanzoni R, Gigante D, Montagnoli L, Frattegiani M, 2006. [Habitat e specie della Direttiva 92/43/CEE ed altri aspetti di rilevanza naturalistica al Lago Trasimeno].[Book in Italian]. AP\&elle, Perugia.

Viehberg F, Mesquita-Joanes F, 2012. Quantitative transfer function approaches in palaeoclimatic reconstruction using Quaternary Ostracods, p. 47-64. In: D.J. Horne, J.A Holmes, J. Rodriguez Lazaro and F. Viehberg (eds.), Ostracoda as proxies for Quaternary climate change. Developments in Quaternary Science 17. Elsevier, Amsterdam.

von Hartmann G, 1964. [Das Problem der Buckelbildung auf Schalen von Ostracoden in ökologischer und historischer Sicht].[Article in German]. Mitt. Hamb. Zool. Mus. Inst. 61:59-66.

Walton W, 1952. Techniques for recognition of living foraminifera. Contrib. Cushman Found. Foram. Res. 3:56-60.

Wohlgemut R, 1914. [Beobachtungen und Untersuchungen über die Biologie der Süßwasserostracoden: Ihr Vorkommen in Sachsen und Böhmen, ihre Lebensweise und ihre Fortpflanzung].[Article in German]. Int. Rev. Hidrobiol. Hydrograp. Biol. Suppl. 4:1-72.

Wouters K, 2002. On the distribution of Cyprideis torosa (Jones) (Crustacea, Ostracoda) in Africa, with the discussion of a new record from the Seychelles. Bull. Inst. Roy. Sci. Nat. Belg. Biol. 72:131-140.

Yu N, Zhao Q, Schornikov EL, Chen L, 2005. [Recent Ostracods from the Taihu Lake].[Article in Chinese with English]. Acta Micropalaeontol. Sinica 22:143-151. 